\title{
The Neonatal Fc Receptor (FcRn) Enhances Human Immunodeficiency Virus Type 1 (HIV-1) Transcytosis across Epithelial Cells
}

\author{
Sandeep Gupta ${ }^{1}$, Johannes S. Gach ${ }^{1}$, Juan C. Becerra ${ }^{1}$, Tran B. Phan ${ }^{1}$, Jeffrey Pudney ${ }^{2}$, \\ Zina Moldoveanu ${ }^{3}$, Sarah B. Joseph ${ }^{4,5}$, Gary Landucci ${ }^{1}$, Medalyn Jude Supnet ${ }^{1}$, Li-Hua Ping ${ }^{4,5}$, \\ Davide Corti $^{6,7}$, Brian Moldt ${ }^{8}$, Zdenek Hel ${ }^{9}$, Antonio Lanzavecchia ${ }^{6,10}$, Ruth M. Ruprecht ${ }^{11}$, \\ Dennis R. Burton $^{8,12}$, Jiri Mestecky ${ }^{3,13}$, Deborah J. Anderson ${ }^{2}$, Donald N. Forthal ${ }^{1 *}$
}

1 Division of Infectious Diseases, Department of Medicine, University of California, Irvine School of Medicine, Irvine, California, United States of America, 2 Department of Obstetrics and Gynecology, Boston University School of Medicine, Boston, Massachusetts, United States of America, 3 Department of Microbiology, University of Alabama at Birmingham, Birmingham, Alabama, United States of America, 4 Lineberger Comprehensive Cancer Center, University of North Carolina at Chapel Hill, Chapel Hill, North Carolina, United States of America, 5 Center for AIDS Research, University of North Carolina at Chapel Hill, Chapel Hill, North Carolina, United States of America, 6 Institute for Research in Biomedicine, Bellinzona, Switzerland, 7 Humabs BioMed SA, Bellinzona, Switzerland, 8 Department of Immunology and Microbial Science, International AIDS Vaccine Initiative Neutralizing Antibody Center and Center for HIV/AIDS Vaccine Immunology and Immunogen Discovery, The Scripps Research Institute, La Jolla, California, United States of America, 9 Department of Pathology, University of Alabama at Birmingham, Birmingham, Alabama, United States of America, 10 Institute of Microbiology, Eidgenössische Technische Hochschule (ETH) Zürich, Zürich, Switzerland, 11 Texas Biomedical Research Institute, San Antonio, Texas, United States of America, 12 Ragon Institute of Massachusetts General Hospital, Massachusetts Institute of Technology, and Harvard University, Boston, Massachusetts, United States of America, 13 Institute of Immunology and Microbiology, First School of Medicine, Charles University, Prague, Czech Republic

\begin{abstract}
The mechanisms by which human immunodeficiency virus type 1 (HIV-1) crosses mucosal surfaces to establish infection are unknown. Acidic genital secretions of HIV-1-infected women contain HIV-1 likely coated by antibody. We found that the combination of acidic $\mathrm{pH}$ and Env-specific lgG, including that from cervicovaginal and seminal fluids of HIV-1-infected individuals, augmented transcytosis across epithelial cells as much as 20-fold compared with Env-specific lgG at neutral pH or non-specific IgG at either $\mathrm{pH}$. Enhanced transcytosis was observed with clinical HIV-1 isolates, including transmitted/ founder strains, and was eliminated in Fc neonatal receptor (FcRn)-knockdown epithelial cells. Non-neutralizing antibodies allowed similar or less transcytosis than neutralizing antibodies. However, the ratio of total:infectious virus was higher for neutralizing antibodies, indicating that they allowed transcytosis while blocking infectivity of transcytosed virus. Immunocytochemistry revealed abundant FcRn expression in columnar epithelia lining the human endocervix and penile urethra. Acidity and Env-specific IgG enhance transcytosis of virus across epithelial cells via FcRn and could facilitate translocation of virus to susceptible target cells following sexual exposure.
\end{abstract}

Citation: Gupta S, Gach JS, Becerra JC, Phan TB, Pudney J, et al. (2013) The Neonatal Fc Receptor (FcRn) Enhances Human Immunodeficiency Virus Type 1 (HIV-1) Transcytosis across Epithelial Cells. PLoS Pathog 9(11): e1003776. doi:10.1371/journal.ppat.1003776

Editor: Ronald C. Desrosiers, Miller School of Medicine, United States of America

Received August 6, 2013; Accepted October 4, 2013; Published November 21, 2013

Copyright: (c) 2013 Gupta et al. This is an open-access article distributed under the terms of the Creative Commons Attribution License, which permits unrestricted use, distribution, and reproduction in any medium, provided the original author and source are credited.

Funding: Research reported in this publication was supported by the National Institute of Allergy and Infectious Diseases of the National Institutes of Health under Award Numbers R01AI102715 (DNF) and U19 AI096398 (DJA). The funders had no role in study design, data collection and analysis, decision to publish, or preparation of the manuscript.

Competing Interests: Davide Corti serves as Senior Vice President and Antonio Lanzavecchia is a scientific advisor for HUMABS BioMed SA. This does not alter our adherence to all PLOS Pathogens policies on sharing data and materials.

*E-mail: dnfortha@uci.edu

\section{Introduction}

Sexual transmission of HIV-1 requires that virus establish infection across genital tract or intestinal tissue. Sexually transmitted infections, other causes of inflammation, and localized trauma may allow susceptible CD4+ target cells at skin or mucosal surfaces to become directly exposed to secretions from infected sexual partners $[1,2]$. However, when skin and mucosa are intact, it remains unclear precisely how HIV-1 gains access to target cells. One possibility is that virus translocates between epithelial cells until susceptible cells are found either in or below the epithelium [3]. Alternatively, Langerhans cells may sample the surface, acquire virus, and move it to areas of abundant target cells [4,5]. Finally, transcytosis of HIV-1 (i.e., movement through cells) has been studied as a potential mechanism to translocate virus from mucosal surfaces to deeperlying CD4+ cells $[6,7,8]$.

Transcytosis offers an explanation for movement of virus across epithelial cells forming tight junctions, which might normally exclude pathogens from moving beyond the surface. However, in vitro, only a very small amount of virus, usually less than $0.3 \%$ of a cell-free virus inoculum, finds its way through cells into the medium bathing basolateral surfaces ([9]). Interactions between HIV-1 Env and several host cell surface molecules, including glycolipids, heparan sulfate proteoglycans and gp340, have been proposed to play a role in transcytosis $[10,11,12,13,14]$. 


\section{Author Summary}

HIV-1 causes a sexually transmitted disease. However, the mechanisms employed by the virus to cross genital tract tissue and establish infection are uncertain. Since cervicovaginal fluid is acidic and HIV-1 in cervicovaginal fluid is likely coated with antibodies, we explored the effect of low $\mathrm{pH}$ and HIV-1-specific antibodies on transcytosis, the movement of HIV-1 across tight-junctioned epithelial cells. We found that the combination of HIV-1-specific antibodies and low $\mathrm{pH}$ enhanced transcytosis as much as 20 -fold. Virus that underwent transcytosis under these conditions was infectious, and infectivity was highly influenced by whether or not the antibody neutralized the virus. We observed enhanced transcytosis using antibody from cervicovaginal and seminal fluids and using transmitted/ founder strains of HIV-1. We also found that the enhanced transcytosis was due to the Fc neonatal receptor (FcRn), which binds immune complexes at acidic $\mathrm{pH}$ and releases them at neutral $\mathrm{pH}$. Finally, staining of human tissue revealed abundant FcRn expression on columnar epithelial cells of penile urethra and endocervix. Our findings reveal a novel mechanism wherein HIV-1 may facilitate its own transmission by usurping the antibody response directed against itself. These results have important implications for HIV vaccine development and for understanding the earliest events in HIV transmission.

With the exception of the acute phase prior to development of anti-HIV-1 immune responses, semen, cervicovaginal, and rectal fluids from HIV-1-infected individuals contain antibodies against HIV-1 Env $[15,16,17]$. The concentration of Env-specific IgG present in such secretions varies considerably from person to person and is usually on the order of 100 to 1,000-fold less than concentrations found in plasma [18]. The presence of Env-specific IgG strongly suggests that some proportion of Env molecules on the surface of infectious virions in genital tract secretions is coated with IgG. Since HIV-1 is successfully transmitted sexually, the coating antibody is either of insufficient quantity or quality to neutralize virus infectivity upon contact with an uninfected partner.

Antibody in genital tract secretions of HIV-1-infected individuals could play a role in facilitating the transport of virus across mucosal epithelia. Such a role is made particularly plausible by the reported expression of the $\mathrm{Fc}_{\mathrm{C}}$ neonatal receptor $(\mathrm{FcRn})$ in human genital mucosal tissue [19]. FcRn is a heterodimeric receptor belonging to the MHC class I family of proteins [20,21]. The expression of $\mathrm{FcRn}$ in endothelial cells is thought to be critical for IgG homeostasis in blood [22], and its expression in placental syncytiotrophoblasts is a key factor in transporting maternal $\mathrm{IgG}$ to the fetal circulation [23]. A characteristic of FcRn is its ability to bind the $\mathrm{Fc}$ region of $\mathrm{IgG}$ at acidic $\mathrm{pH}$ and to release it at neutral $\mathrm{pH}$ [24]. This $\mathrm{pH}$-dependent binding allows the transport of intact IgG or of IgG immune complexes from luminal surfaces bathed in acidic fluids, for example, cervicovaginal secretions, to basolateral surfaces exposed to a neutral intracellular milieu [19].

Cervicovaginal secretions are maintained at acidic $\mathrm{pH}$ by acidproducing bacteria that make up part of the normal vaginal microbiota [25]. Although perturbations of normal microbiota, such as occur with bacterial vaginosis, raise the $\mathrm{pH}$, the secretions generally remain in the acidic range [26,27]. Semen rapidly neutralizes cervicovaginal secretions, but the extent of the $\mathrm{pH}$ change is variable. For example, a large amount of ejaculate may raise the $\mathrm{pH}$ to the neutral range, whereas a small amount may not
$[28,29]$. The $\mathrm{pH}$ of rectal secretions ranges from about 6.8 to 7.2 [30].

Given that HIV-1 in genital tract secretions may be complexed with IgG antibody, that female genital tract secretions are acidic, and that FcRn has been demonstrated in genital tract tissues, we evaluated the role of $\mathrm{pH}$ and antibody on transcytosis of HIV-1 through polarized epithelial cells.

\section{Results}

\section{Acidic $\mathrm{pH}$ and Env-specific lgG enhance transcytosis of HIV-1}

To investigate the effect of low $\mathrm{pH}$ and antibody on HIV-1 transcytosis across epithelial cells forming tight junctions, we exposed the apical surface of HEC-1A cells to HIV-1 at pH 6.0 or 7.4 with or without HIV-1-specific IgG (HIVIG). Virus was quantified in the medium bathing the basolateral cell surface ("subnatant fluid") by RT-PCR and, although detectable as early as six hours after exposure of virus to the apical cell surface, the quantity was greater at 12 hours (Figure S1) [8]. Thus, in subsequent experiments, transcytosis was measured at 12 hours. Using HIV-1 Us712 $_{2}$, a clade B R5 clinical isolate, HIVIG enhanced transcytosis in a dose-dependent manner when virus and antibody were exposed to the apical surface at $\mathrm{pH} 6.0$ (Figure 1A). There was no increase in transcytosis with HIVIG at $\mathrm{pH} 7.4$ or with HIV-negative IgG (IVIG) at $\mathrm{pH} 6.0$ or 7.4. We found similarly enhanced transcytosis using additional R5 as well as X4 and X4/ R5 strains (Figure 1B). Importantly, transcytosis of four of five clade C transmitted/founder Env-pseudotyped viruses was enhanced in a $\mathrm{pH}$ and antibody-dependent manner (Figure 1C). Enhanced transcytosis with HIV-1-specific antibody at low $\mathrm{pH}$ also occurred with T84 colon carcinoma cells (Figure S2).

Since sexual transmission may occur with small amounts of virus, we investigated if $\mathrm{pH}$ - and antibody-dependent enhancement of transcytosis could occur at very low HIV-1 inocula. Using HIVIG or the anti-gp41 monoclonal antibody (mAb) 2F5, we found that transcytosis occurred with virus inocula as low as $2 \mathrm{pg}$ of p24 (about 60,000 RNA copies) with HIVIG and $0.02 \mathrm{pg}$ of p24 (about 500 RNA copies) with 2F5, amounts too small to be detectable in subnatant fluid in the absence of low $\mathrm{pH}$ and HIV-1specific antibody (Table 1). These quantities of virus are within the range observed in seminal and cervicovaginal fluids of HIVinfected individuals $[31,32,33]$.

\section{Enhanced transcytosis is mediated by FcRn}

The impact of both antibody and low $\mathrm{pH}$ suggested FcRn involvement $[34,35]$. We knocked down $\mathrm{F}_{\mathrm{CR}} \mathrm{n}$ in HEC-1A cells, verifying lower expression by flow cytometry and by Western blot (Figure S3A). The knock-down HEC-1A cells attained the same level of electrical resistance as did the wild-type cells (data not shown), indicating that FcRn knockdown did not affect the ability to form tight junctions. Unlike with wild-type HEC-1A cells, there was no enhanced transcytosis with FcRn-knockdown HEG-1A cells when either mAb 2F5 (Figure 2A) or polyclonal HIVIG (data not shown) were used. We also evaluated $\mathrm{FC}_{\mathrm{C}}$ mutants of the HIV-1 Env-specific mAb b12. A mutant designed to abrogate FcRn binding (I253A), markedly lowered transcytosis compared with wild-type b12 (Figure 2B) [36]. The second mutant (M428L), designed to bind with higher affinity to $F_{C} R n$, increased transcytosis compared with wild-type b12 (Figure 2B) [37]. Binding to HIV-1 JRFL gp120 (Figure S3B) and neutralization of HIV-1 JRFL (Figure S3G) were nearly equivalent for the wild-type and $\mathrm{Fc}_{\mathrm{C}}$ mutant versions of b12, indicating that the $\mathrm{Fc}_{\mathrm{c}}$ mutations did not affect Fab-antigen binding. Blockade of FcRn with 
A

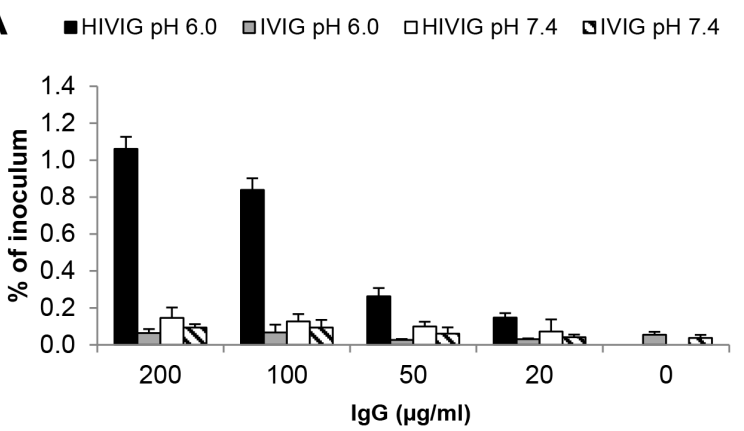

B

口 $6.0 \quad \square \mathrm{pH} 7.4$

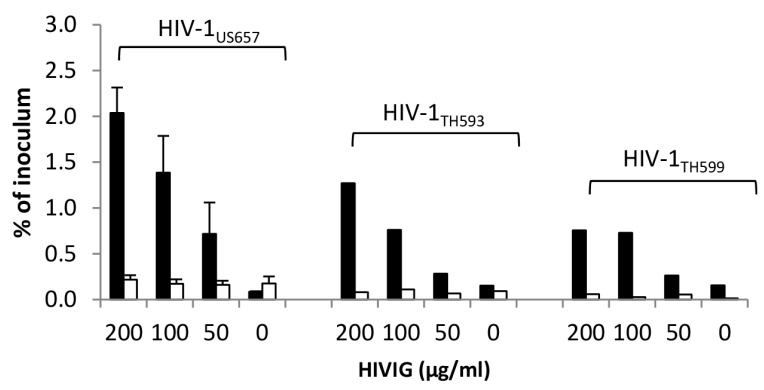

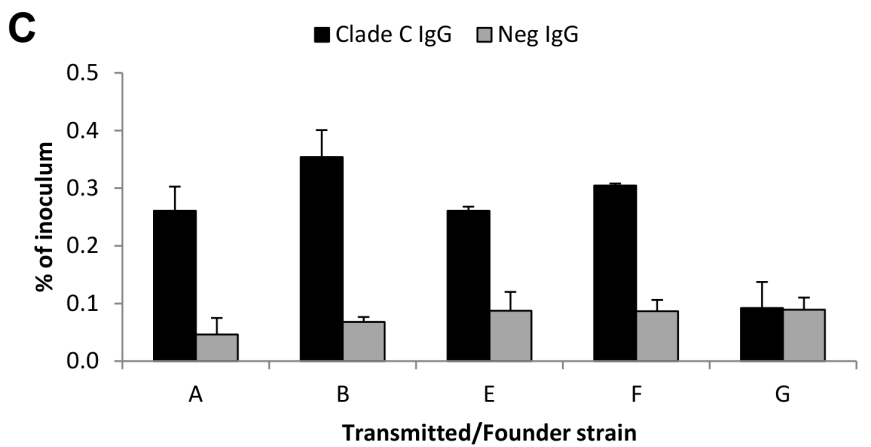

Figure 1. HIV-specific IgG and low pH enhance HIV-1 transcytosis. (A) Indicated concentrations of HIV-specific IgG (HIVIG) or control IgG (IVIG) and 2 ng of p24 (average of 3,814,910 RNA copies) of HIV-1 us712 were added to the apical surface of HEC-1A cells at pH 6.0 or 7.4. Subnatant fluid virus was quantified by RT-PCR and expressed as a percentage of inoculum applied to the apical surface of the HEC-1A cells. Data represent mean+SE of eight independent experiments (some antibody concentrations were tested less frequently); $p=3.6 \times 10^{-8}$ comparing HIVIG at $\mathrm{pH} 6.0$ with IVIG at pH 6.0; $p=3.4 \times 10^{-6}$ comparing HIVIG at pH 6.0 with HIVIG at pH 7.4 (Kruskal-Wallis test). (B) Enhanced transcytosis occurs with multiple

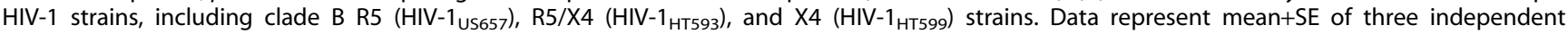
experiments for HIV-1 $1_{\text {us657 }}$ (average inoculum $=1,096,491$ RNA copies) and one experiment each for HIV-1 HT593 $_{\text {(inoculum }=2,450,255 \text { RNA copies) }}$ and HIV-1 ${ }_{\text {HT599 }}$ (inoculum $=1,477,802$ RNA copies). (C) IgG enhances transcytosis of clade C transmitted/founder Env-pseudotyped virus. IgG from serum of clade C-infected or uninfected subjects was used at $50 \mu \mathrm{g} / \mathrm{ml}$. Results are mean+SE of two independent experiments (average inoculum $=1,556,522$ RNA copies) at $\mathrm{pH} 6.0$ only; $p=0.008$ comparing clade $\mathrm{C}$ and HIV-Neg lgG (Kruskal-Wallis test). doi:10.1371/journal.ppat.1003776.g001

anti-FcRn antibody and inhibition of endosomal acidification by bafilomycin Al also substantially reduced or eliminated enhanced transcytosis (Figure S3D-F), as did competition between the nonHIV-1-specific mAb Den3 and the anti-HIV-1 Env mAb VRC01 (Figure S3G). Consistent with other investigations of Fc-FcRn interactions, maximally enhanced transcytosis occurred at $\mathrm{pH} 5.5-$ 6.0, with some enhanced transcytosis apparent at $\mathrm{pH} 4.5$ and 6.5 (Figure S3H) [38,39]. Since FcRn binds to IgG and not to IgA, we

Table 1. Enhancement of HIV-1 transcytosis occurs with low viral inocula ${ }^{1}$.

\begin{tabular}{|c|c|c|c|c|}
\hline \multicolumn{2}{|l|}{ Inoculum } & \multicolumn{3}{|c|}{ Subnatant Fluid (RNA copies) } \\
\hline p24 (pg) & RNA copies & No antibody & HIVIG & mAb 2 F5 \\
\hline 2000 & $64,295,720$ & 250,028 & 886,060 & $3,782,575$ \\
\hline 200 & $7,949,017$ & 29,223 & 116,640 & 362,063 \\
\hline 20 & 652,246 & 1,983 & 10,328 & 34,765 \\
\hline 2 & 62,343 & neg & 753 & 4,868 \\
\hline 0.2 & 8,392 & neg & neg & 658 \\
\hline 0.02 & 523 & neg & neg & 120 \\
\hline
\end{tabular}

${ }^{1}$ Transcytosis carried out at pH 6.0 with $200 \mu \mathrm{g} / \mathrm{ml}$ of HIVIG or $100 \mu \mathrm{g} / \mathrm{ml} \mathrm{mAb}$ $2 \mathrm{F5}$; data are representative of three independent experiments.

doi:10.1371/journal.ppat.1003776.t001 compared two different IgG1 mAbs, b12 and HGN194, with their IgA class-switched versions. Both IgG1 mAbs enhanced transcytosis of HIV-1 JRFL pseudoviruses and SHIV I157ipEL-p $_{\text {at }}$ pH 6.0, whereas the IgA class-switched versions $\operatorname{did}$ not (Figure 2C and 2D). In fact, as reported, dimeric IgA1 HGN194 inhibited transcytosis [40]. Thus, enhanced transcytosis at low $\mathrm{pH}$ in the presence of specific antibody is mediated by IgG and is dependent on FcRn.

Using $50 \mu \mathrm{g} / \mathrm{ml}$ of VRC01 or Den3, transcytosis of IgG alone increased approximately 3 fold from about $0.4 \%$ at $\mathrm{pH} 7.4$ to about $1.3 \%$ at pH 6.0 (Figure S4). However, the effect of FcRnmediated transcytosis on IgG alone does not appear as strong as the effect on IgG immune complexes, where, for example, with complexes made with $50 \mu \mathrm{g} / \mathrm{ml}$ of VRC01 or $2 \mathrm{~F} 5$, there was about an 8-fold increase in transcytosis under conditions allowing FcRn engagement. This difference may be due to the contribution of fluid phase uptake of IgG by the epithelial cells at both $\mathrm{pH} 6.0$ and $\mathrm{pH}$ 7.4; $\mathrm{IgG}$ thus internalized can engage $\mathrm{FcRn}$ in acidic endosomes and be shuttled to the basolateral side of the cells [41]. The internalization of immune complexes, on the other hand, likely depends primarily on FcRn engagement at the surface of the cell at $\mathrm{pH}$ 6.0.

Infectivity of transcytosed virus is affected by antibody function

We evaluated the ability of HIVIG and a panel of mAbs with variable neutralizing activities to mediate $\mathrm{pH}$-dependent 
A

च2F5 pH $6.0 \square$ Den3 $\mathrm{pH} 6.0 \quad \square 2 \mathrm{~F} 5 \mathrm{pH} 7.4 \quad \square$ Den3 $\mathrm{pH} 7.4$

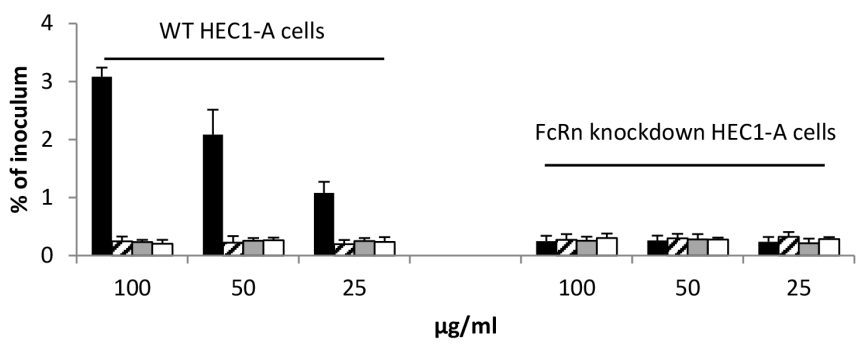

C

- IgG1 HGN194 घIgG1 b12

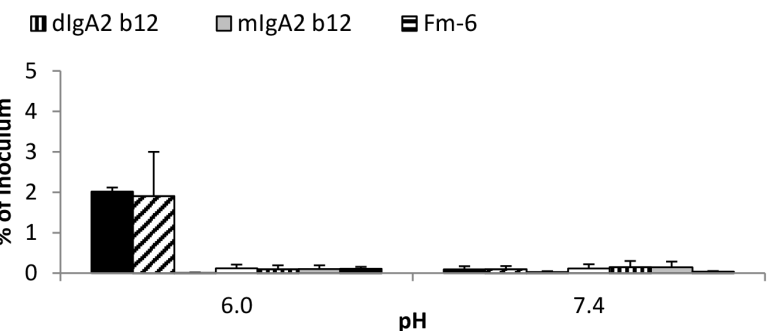

B

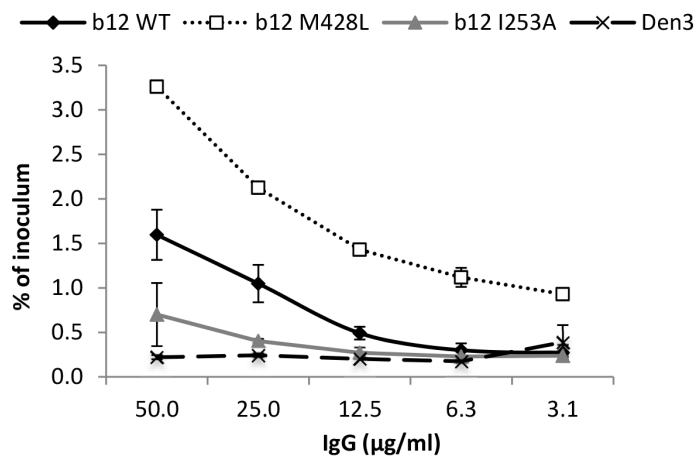

D

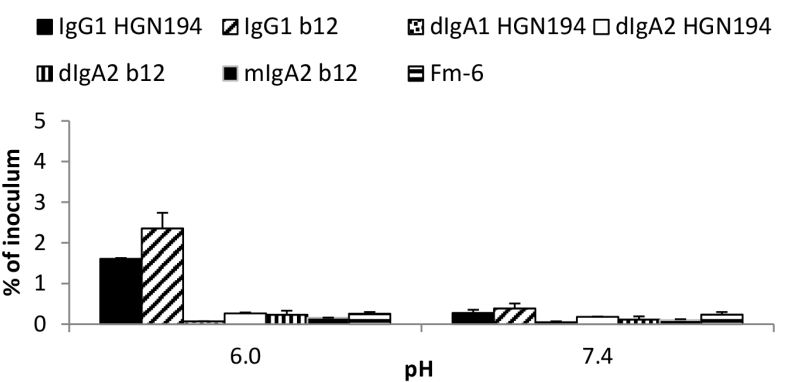

Figure 2. FcRn is responsible for pH/antibody-mediated enhanced transcytosis of HIV-1. (A) Knockdown of FcRn eliminates enhanced transcytosis. Transcytosis was performed with the wild-type and FcRn knockdown HEC-1A cells in parallel at pH 6.0 or 7.4 using HIV-1 us657 (average inoculum $=712,745 \mathrm{RNA}$ copies) and $\mathrm{mAb} 2 \mathrm{~F} 5$ or control mAb (Den3). Results represent mean $+\mathrm{SE}$ of three independent experiments; $p=0.032$ comparing wild type and knockdown cells using $2 \mathrm{~F} 5$ at pH 6.0 (repeated-measures ANCOVA). (B) An Fc mutant of mAb b12 that increases FcRn binding (M428L) increases transcytosis of HIV-1 JRFL $_{\text {at }}$ pH 6.0, whereas a mutant that decreases FcRn binding (I253A) reduces transcytosis. Data represent the mean+SE of two independent experiments. (C)(D) IgG1, but not IgA1 or IgA2, enhances transcytosis at pH 6.0. mAb IgG1 b12 or its dimeric (dlgA2 b12) and monomeric (mlgA2 b12) class-switched versions and mAb lgG1 HGN194 or class switched variants dlgA1 HGN194 and dlgA2 HGN194 were tested for transcytosis using (B) HIV-1 JRFL Env-pseudotyped virus (average inoculum=2,269,529 RNA copies) or (C) SHIV 1157ipEL-p (average inoculum $=682,724$ RNA copies). $\mathrm{Fm}-6$ is an anti-SARS coronavirus lgG1 used as a negative control. All $\mathrm{mAbs}$ were tested at $50 \mu \mathrm{g} / \mathrm{ml}$. Data represent mean+SE of two independent assays for each virus. With either virus, IgG1 versions of the mAbs allow significantly more transcytosis at

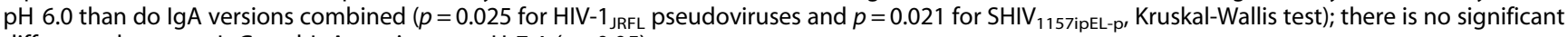
difference between IgG and IgA versions at $\mathrm{pH} 7.4(p>0.05)$.

doi:10.1371/journal.ppat.1003776.g002

transcytosis with fully infectious $\mathrm{HIV}-1_{\mathrm{JRFL}} ; 50 \%$ inhibitory concentrations $\left(\mathrm{IC}_{50} \mathrm{~s}\right)$ of the antibodies ranged from 0.06 to $>50 \mu \mathrm{g} / \mathrm{ml}$ (Fig. 3E). Both poorly neutralizing antibodies (HIVIG and mAbs b6 and F240; Figure 3A) and neutralizing mAbs (4E10, 2F5, 2G12, VRC01, and b12; Figure 3B) enhanced transcytosis at $\mathrm{pH} 6.0$. At $50 \mu \mathrm{g} / \mathrm{ml}$, transcytosis correlated directly with $\mathrm{mAb}$ binding to $\mathrm{HIV}-1_{\text {JRFL }}$ (Spearman rho $=0.75$; $p=0.052)$ and inversely with the $\mathrm{IC}_{50}$ of the mAbs (Spearman $\left.r h_{0}=-0.71 ; p=0.050\right)$ (Figure S5). At $\mathrm{pH} 6.0$, all Env-specific mAbs and HIVIG mediated transcytosis of virus that infected TZM-bl cells (Figure 3G and D). However, there was a strong correlation between the amount of transcytosed infectious virus and the neutralizing activity $\left(\mathrm{IC}_{50}\right)$ of the antibody that mediated the transcytosis (Spearman's $r h o=0.86 ; p=0.001$ ). Virus whose transcytosis was mediated by poorly neutralizing antibodies HIVIG, F240 and b6, at least at concentrations of 100 and $50 \mu \mathrm{g} / \mathrm{ml}$, was more infectious than virus which crossed the epithelial cells in a non-FcRn-dependent manner (i.e., in the presence of Den 3 control mAb) (Fig. 3C). Conversely, transcytosis mediated by antibodies with the lowest $\mathrm{IC}_{50}$ s, such as VRC01 and b12, resulted in less infectious virus than was observed with the Den 3 control antibody (Figure 3D). Thus, strong binding activity results in more FcRn-dependent transcytosis, whereas strong neutralizing activity renders the transcytosed virus less infectious.
This point is further illustrated by the ratio of percenttranscytosed:percent-infectious virus (Figure 3E). For example, for every infectious unit, about 30 times more virus is transcytosed with VRC01 than with HIVIG (Figure 3E). Note that independently of transcytosis, HIV-1 JRLF infectivity on TZM-bl cells increased about 3.5-fold after incubation of virus for 12 hours at $\mathrm{pH} 6.0$ compared with $\mathrm{pH} 7.4$; however, $\mathrm{IC}_{50 \text { s }}$ were very similar $(<15 \%$ difference) at the two $\mathrm{pH}$ values ( $\mathrm{pH}$ comparisons done for 2F5 and VRC01 only; data not shown). Virus infectivity was essentially abrogated after a 12-hour incubation at $\mathrm{pH} 4.0$ (data not shown).

\section{IgG from genital tract secretions enhances transcytosis at} $\mathrm{pH} 6.0$

We next determined whether IgG purified from cervicovaginal fluid and from seminal fluid could enhance transcytosis at low $\mathrm{pH}$. Using IgG from cervicovaginal fluid of three HIV-infected women and from seminal fluid of three infected men, enhanced transcytosis occurred at $\operatorname{IgG}$ concentrations well within their expected range in genital tract secretions (Figure $4 \mathrm{~A}$ and $4 B$ ) [18]. The ability of genital tract IgG to mediate transcytosis correlated strongly with infectious virus capture activity by the IgG (Spearman's $r h o=0.94, p=0.005$; Figure 4C) and less so with binding to monomeric Env glycoprotein from the same virus strain 
A

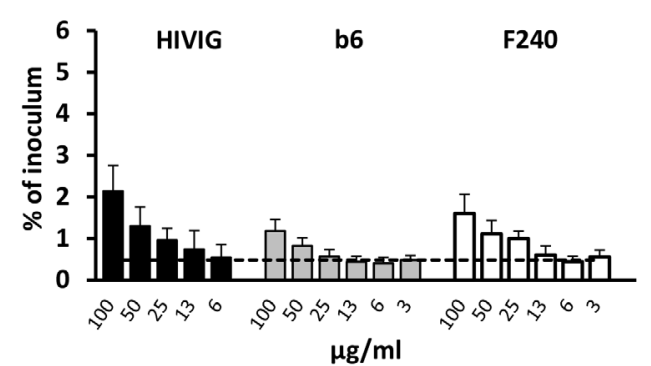

C
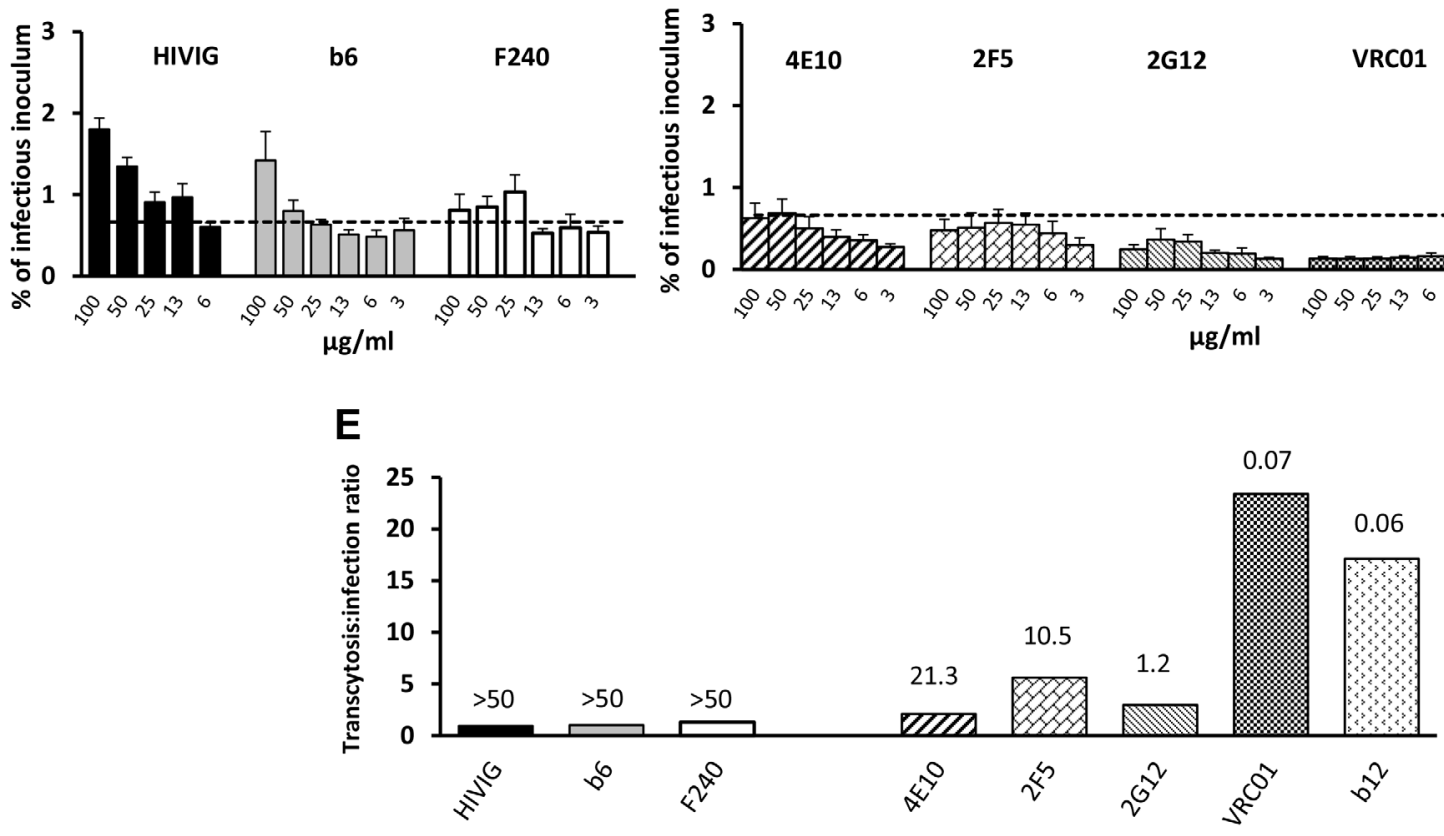

B
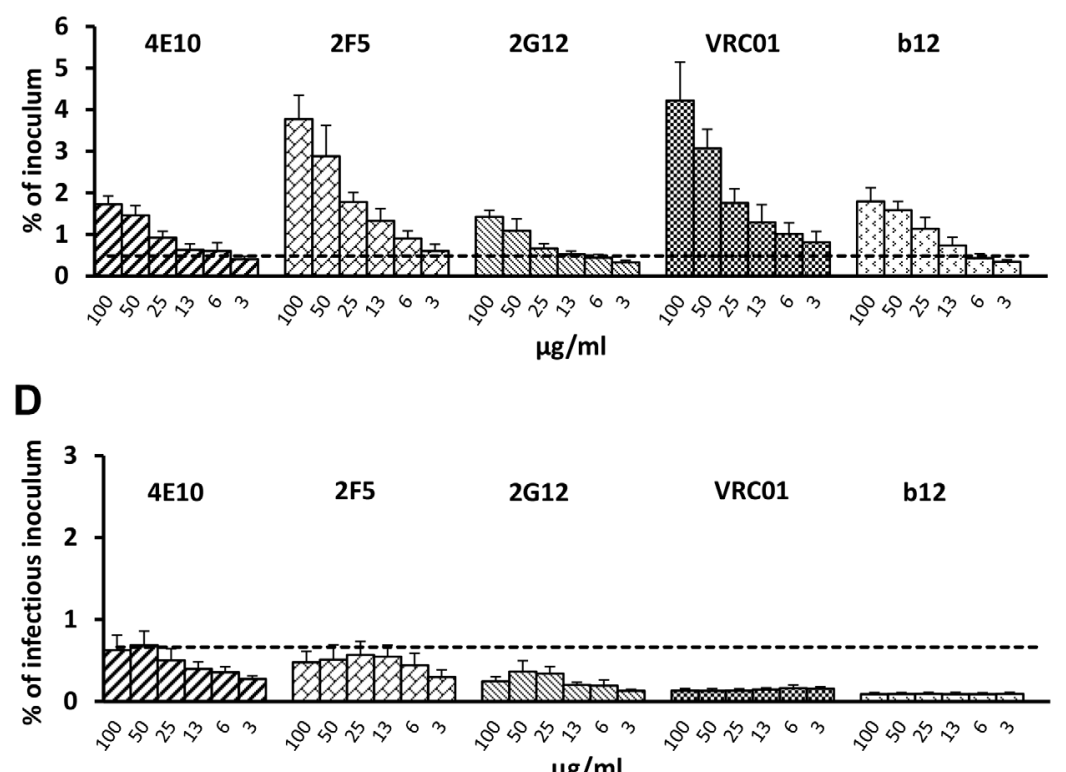

$\mu \mathrm{g} / \mathrm{ml}$

Figure 3. Effect of antibodies on transcytosis and infectivity. Transcytosis ( $\mathrm{pH}$ 6.0) of HIV-1 JRFL by (A) poorly neutralizing HIVIG and $\mathrm{mAbs}$ b6 and F240 and (B) neutralizing mAbs 4E10, 2F5, 2G12, VRC01 and b12. HIV-1 JRFL average inoculum =3,990,745 RNA copies. Dotted lines represent mean +2 SD of $\%$ virus transcytosed with Den3 control mAb. There are significant differences between the Den3 control and $2 \mathrm{~F} 5$ ( $p=0.0002)$, b12 $(p=0.007), 2 \mathrm{G} 12(p=0.006), 4 \mathrm{E} 10(p=0.001)$, b6 $(p=0.008), \mathrm{F} 240(p=0.002)$, and VRC01 $(p=0.003)$ and between IVIG (not shown) and HIVIG $(p=0.033)$ (repeated-measures ANCOVA). (C) Infectivity of HIV-1 JRFL whose transcytosis was mediated by poorly neutralizing or (D) neutralizing antibodies. All antibodies resulted in transcytosed virus that was infectious ( $>$ mean+2 SDs of relative light units [RLUs] from uninfected TZM-bl cells [dotted line]); average infectious inoculum $=244,601$ RLUs. Compared to Den3 control, less infectious virus was transcytosed with b12 $\left(p=3.4 \times 10^{-11}\right)$, VRC01 $\left(p=6.9 \times 10^{-10}\right)$, and $2 \mathrm{G} 12\left(p=3.6 \times 10^{-4}\right)$ (repeated-measures ANCOVA). Compared to Den3, there was more infectious virus with F240 ( $p=0.036)$ and with b6 $(p=0.068)$. Compared to IVIG (not shown), HIVIG resulted in more infectious virus $(p=0.003)$. Data in A-D represent mean+SE of three or four independent experiments. (E) Ratio of \% transcytosed:\% infectious virus from data in (A) and (B) using $50 \mu \mathrm{g} / \mathrm{ml} \mathrm{of}$ antibody. Numbers over bars represent $\mathrm{IC}_{50}$ against HIV-1 JRFL.

doi:10.1371/journal.ppat.1003776.g003

$\left(\mathrm{HIV}-1_{\mathrm{US} 657}\right)(r h o=0.65, p=0.16 ;$ Figure S6). None of the genital tract IgGs were able to neutralize $\mathrm{HIV}_{\mathrm{US} 657}$, the clinical R5 strain used in these experiments, at IgG concentrations as high as $50 \mu \mathrm{g}$ / $\mathrm{ml}$ (not shown). Consistent with HIVIG and the non-neutralizing $\mathrm{mAbs}$, higher concentrations of genital tract IgGs generally resulted in greater infectivity of the transcytosed virus (Figure 4D and 4E).

\section{FcRn is expressed in genital tract tissues}

FcRn expression was previously reported in human uterine and vaginal epithelial cells [19]. Using immunohistochemistry to survey FcRn protein expression at various sites in the human genital tract, we detected abundant FcRn expression in columnar epithelial cells lining the human penile urethra (Figure 5A and 5D; Figure S7A and S7D) and endocervix (Figure 5B and 5E;
Figure S7B and S7E). In contrast, little to no $F_{C} R n$ protein was observed in vaginal/ectocervical squamous epithelia, and expression occurred only in the basal epithelial layer (Figure 5C and 5F; Figure S7G). A similar staining pattern was observed in foreskin tissue (data not shown).

\section{Discussion}

Female genital tract secretions are often acidic, and the secretions of HIV-infected individuals have antibody capable of coating virus contained in those secretions. These facts led us to explore the role of antibody and low $\mathrm{pH}$ on transcytosis of HIV-1 across epithelial cells. Our primary finding is that at acidic $\mathrm{pH}, \mathrm{IgG}$ enhances transcytosis of HIV-1 clinical isolates, including transmitted/founder Env-pseudotyped strains. Moreover, antibody from 
A

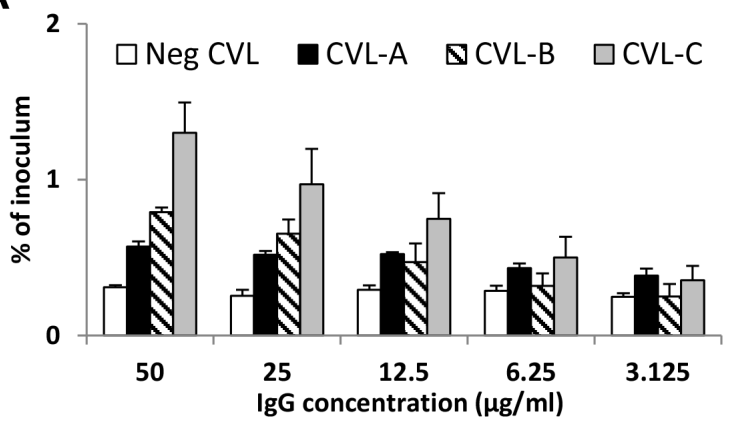

B

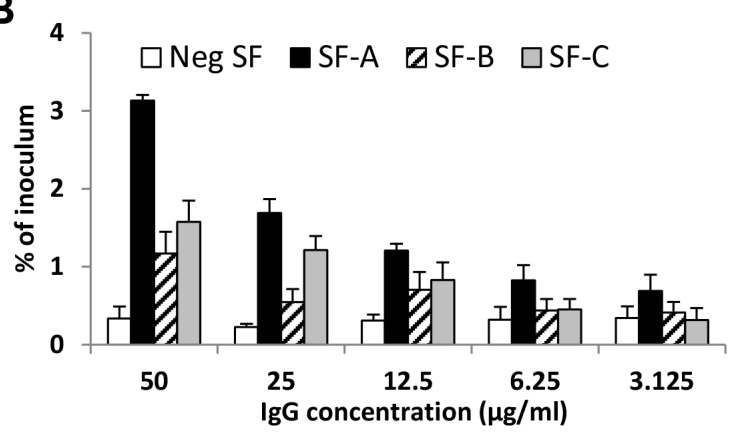

C

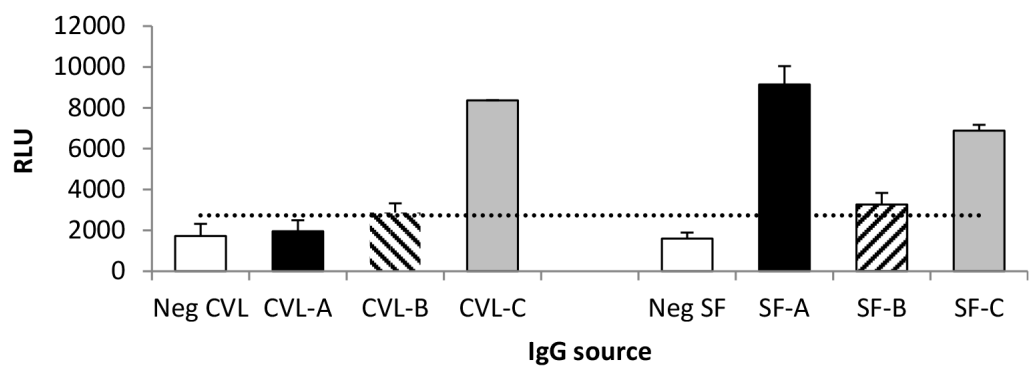

D

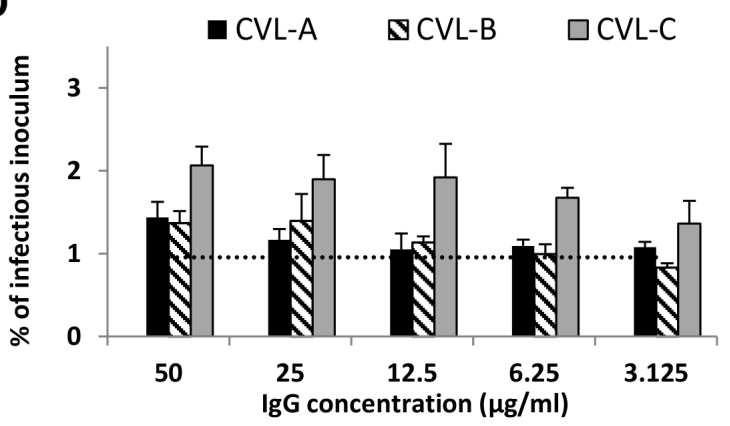

E

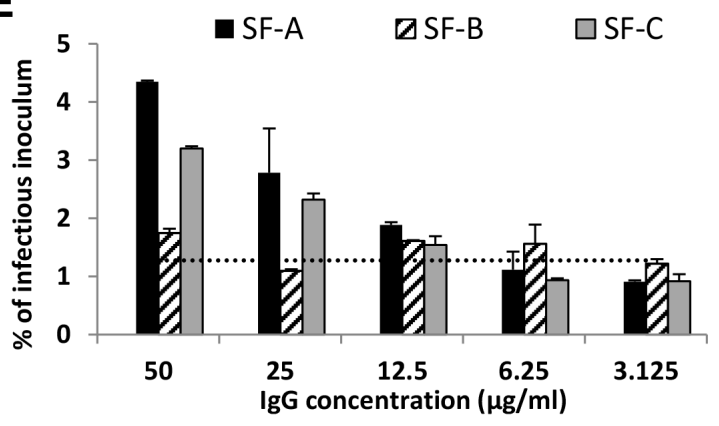

Figure 4. IgG purified from genital tract secretions enhances transcytosis at pH 6.0. (A) Cervicovaginal (CVL) fluid IgG from three HIVinfected women (CVL-A, CVL-B, and CVL-C) mediates enhanced transcytosis of HIV-1 us657 (average inoculum=2,479,412 RNA copies) at pH 6.0. (B) Similarly, IgG purified from seminal fluid of three HIV-infected men (SF-A, SF-B, and SF-C) enhances transcytosis of HIV-1 Us657 (average inoculum $=622,642$ RNA copies) at $\mathrm{pH}$ 6.0. (C) Infectious HIV-1 capture by antibody in CVL and seminal fluids. Virus was captured by the indicated lgG $(5 \mu \mathrm{g} / \mathrm{ml})$ and added to TZM-bl cells; infection was then quantified by RLUs. Infectious virus capture correlates with transcytosis at pH 6.0 (Spearman's $r h o=0.94 ; p=0.005$ ). Shown is the mean+SE of duplicate samples. The dotted line represents a negative cutoff based on the mean+2 SD of IgG from cervicovaginal or seminal fluid of HIV-uninfected subjects. (D) (E) Both cervicovaginal fluid IgG (D) and seminal fluid lgG (E) mediate transcytosis of infectious virus. Average infectious inoculum $=1,160,894$ and 1,913,288 relative light units [RLUs] for cervicovaginal and seminal fluid, respectively. The dotted lines represent negative cutoffs based on the mean+2 SD of IgG from cervicovaginal and seminal fluid of the HIV-uninfected subjects. Data shown (A, B, D, and $\mathbf{E})$ are mean+SE of two independent assays.

doi:10.1371/journal.ppat.1003776.g004

both cervicovaginal and seminal fluid mediates enhanced transcytosis at low $\mathrm{pH}$. The enhanced transcytosis is abrogated by blocking or knocking down FcRn, which is known to bind IgG and immune complexes at low $\mathrm{pH}$ and release them at neutral $\mathrm{pH}[24,42]$. We also establish that virus translocated across epithelial cells after incubation with antibody at low $\mathrm{pH}$ remains infectious. Although neutralizing antibodies generally promote more transcytosis, the transcytosed virus is relatively less infectious than virus whose transcytosis is mediated by non-neutralizing antibodies. Finally, we demonstrate abundant FcRn protein expression in columnar epithelial cells of the human endocervix and penile urethra, suggesting that these sites could play a major role in FcRn-mediated immune complex transcytosis.
Our results indicate that $\mathrm{F}_{\mathrm{CRn}}$ may be responsible for shuttling IgG-bound HIV-1 across epithelial cells in the genital tract. This is consistent with other studies that have highlighted a role for FcRn in immune complex shuttling across tissues [34,35,43]. Mice expressing human FcRn in intestinal epithelial cells were able to deliver IgG to the luminal intestinal surface, which could then bind to its cognate antigen and return the immune complex back to the lamina propria for presentation by dendritic cells to CD4+ $\mathrm{T}$ cells [34]. In addition, cytomegalovirus (CMV) applied to human placental explants from women with high anti-CMV neutralizing antibody activity was rapidly transcytosed across syncytiotrophoblasts and captured by villus macrophages [35]. Under these conditions, the virus did not replicate. However, in 

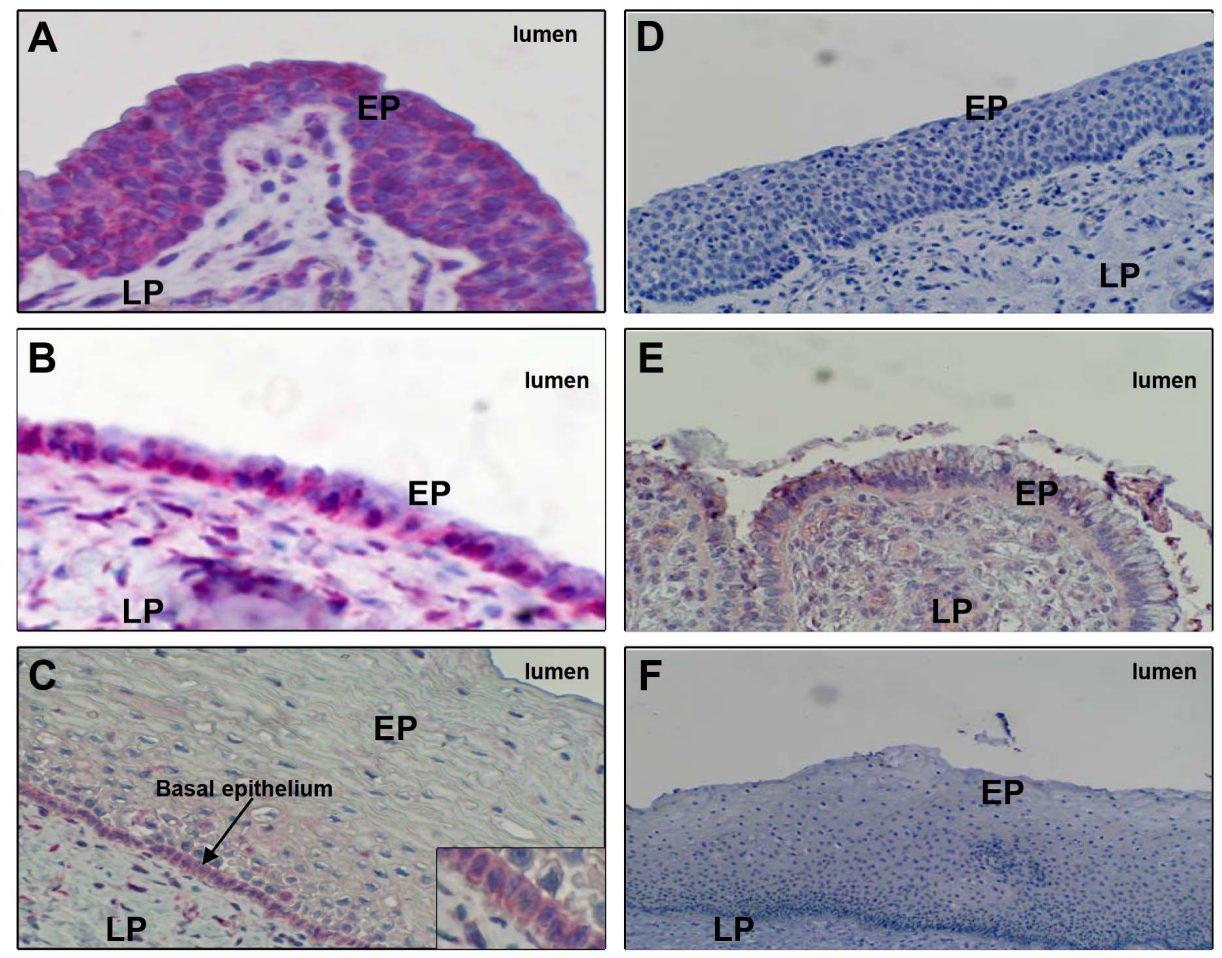

Figure 5. FcRn expression in human genital tissues, detected by immunohistochemistry. FcRn expression (red stain) in columnar epithelia lining (A) the penile urethra (representative of 16 donors), (B) endocervix (representative of five donors), or (C) vagina (representative of 12 donors). Tissues were also stained with negative control (non-specific) IgG and processed through the same immunohistochemistry procedure: (D) penile urethra, (E) endocervix, and (F) vaginal epithelia. Epithelia (EP) and lamina propria (LP) are labeled. Staining was performed on paraffin-embedded specimens.

doi:10.1371/journal.ppat.1003776.g005

explants from GMV-seropositive women with low or undetectable neutralizing antibodies, virus replication readily occurred in cytotrophoblasts underlying an intact, uninfected syncytiotrophoblast layer. Thus, it appeared that neutralizing antibody inhibited infection after allowing virus to cross the syncytiotrophoblast layer. On the other hand, non-neutralizing antibody allowed or even promoted infection. Syncytiotrophoblasts express high levels of $F_{c R n}$, and when FcRn on explants was blocked, IgG-virion complexes were not transported across the surface [35]. Just as we found with HIV-1, FcRn-mediated transcytosis of CMV occurred with both neutralizing and poorly neutralizing antibody, but transcytosed virus remained infectious only when complexed with poorly neutralizing antibody. Finally, immunohistochemical staining of placentas from in utero infections were consistent with this model of FcRn-mediated transcytosis [35].

To our knowledge, ours is the first study to investigate transcytosis using virus coated with HIV-specific antibody in an acidic environment that mimics that of the female genital tract. Our in vitro observations are applicable to male-to-female transmission via vaginal intercourse, where enhanced transcytosis could facilitate infection. In this regard, $\mathrm{Li}$ et al. reported FcRn expression and bidirectional IgG transport in a human vaginal tissue model [19]. Although we did not detect FcRn in the apical layers of vaginal epithelium, we did detect abundant FcRn expression in columnar endocervical epithelial cells. These cells may be exposed to acidic vaginal secretions where they occur at the cervical os. Furthermore, cervical ectopy, a common condition characterized by the extension of endocervical columnar epithelium into the ectocervix and upper vagina, has been implicated as a risk factor for HIV-1 infection $[44,45]$. Prevalent in reproductive-age women, these cervical lesions are exposed to vaginal $\mathrm{pH}$ conditions and could provide portals for FcRn-mediated male-to-female HIV-1 transmission [46]. FcRn was also found, though not consistently, in basal epithelial cells of the vagina. These cells lie deep in the epithelium and are unlikely to come in contact with acidic secretions and HIV-1 immune complexes unless there were trauma or substantial thinning of the overlying squamous epithelium. It is important to note that seminal fluid can rapidly raise the $\mathrm{pH}$ of cervicovaginal secretions to levels which would not support immune complex-FcRn binding. However, the $\mathrm{pH}$ of cervicovaginal fluid following ejaculation is dependent on the quantity of the ejaculate and may stay within an acidic range [29]. Furthermore, HIV is present in preejaculate secretions and could be introduced into the female genital tract prior to ejaculation [47].

With respect to female-to-male transmission, the penis comes in contact with vaginal secretions that would remain at acidic $\mathrm{pH}$ at least until ejaculation, allowing time for exposure of penile tissues, including the foreskin and urethra, to IgG-coated virus at low $\mathrm{pH}$ $[28,29]$. Our demonstration of abundant FcRn on human penile urethral epithelium supports a model where exposure to antibodybound HIV-1 might lead to enhanced female-to-male transmission. It should be noted that the $\mathrm{pH}$ of vaginal secretions is typically about 4, which is below the $\mathrm{pH}$ required for $\mathrm{Fc}_{\mathrm{c}} \mathrm{F}_{\mathrm{C} n} \mathrm{Rn}$ binding [48]. However, there is substantial variability in normal vaginal $\mathrm{pH}[26,48]$, and we did begin to observe enhanced transcytosis at $\mathrm{pH} 4.5$ (Figure S3H). Furthermore, it is possible that there is some buffering effect of foreskin and urethral secretions. The foreskin, whose presence increases HIV infection rate, could trap secretions containing HIV-1 immune complexes and thereby allow greater urethral exposure to infected material 
within the $\mathrm{pH}$ range of $\mathrm{F}_{\mathrm{C}-\mathrm{F}} \mathrm{Rn}$ binding [49]. Additionally, bacterial vaginosis, a condition associated with an increased risk of female-to-male (as well as male-female) HIV transmission, results in vaginal secretions ideal for $F_{C}-F_{C} R n$ binding $[26,27,50]$. Exposure of penile tissues to the $\mathrm{pH}$ range of $\mathrm{Fc}_{\mathrm{c}} \mathrm{F} \mathrm{F} \mathrm{R}$ binding may also occur after ejaculation, since complete neutralization of vaginal acidity may not occur immediately or at all [29]. It is also possible, though less likely, that FcRn mediates HIV transmission via the penis during insertive anal intercourse, where the penis may come into contact with slightly acidic rectal secretions [30].

The finding that IgG from cervicovaginal and seminal fluids obtained from HIV-infected individuals mediate enhanced transcytosis of infectious virus further suggests the biological relevance of our results. Cervicovaginal and seminal fluids are reported to contain an average of $\sim 3 \mu \mathrm{g} / \mathrm{ml}$ and up to $\sim 15 \mu \mathrm{g}$ / $\mathrm{ml}$ of Env-specific IgG [18]. Four of the six samples we evaluated bound to infectious HIV-1 at $5 \mu \mathrm{g} / \mathrm{ml}$. Moreover, all of our samples mediated transcytosis at $\leq 12.5 \mu \mathrm{g} / \mathrm{ml}$ of total $\mathrm{IgG}$, well below total IgG concentrations found in genital secretions of HIVinfected men and women [18]. Even during acute HIV infection, when the risk of transmission to an uninfected partner is highest, 23 of 23 subjects $(100 \%)$ were reported to have anti-gp4l IgG antibodies and $40 \%$ had anti-gp $120 \mathrm{IgG}$ antibodies in cervicovaginal and seminal fluids [17]. Anti-gp41 IgG levels were on average 11-fold higher than gp41-specific IgA levels; anti-gp41 IgM was found less frequently and in lower quantity. Thus, HIV-1 immune complexes are likely to occur in mucosal secretions, are likely to contain predominantly IgG, and under acidic conditions, would be subject to FcRn-mediated transcytosis in an exposed host.

The relevance of our findings is also supported by our demonstration that transcytosis of transmitted/founder strains of HIV-1 Env pseudotyped virus is enhanced by antibody. We are currently evaluating whether transmitted/founder strains, in comparison with chronic strains, are preferentially transcytosed, which would be consistent with a report showing a higher sensitivity of clade B transmitted/founder strains to anti-Env antibody binding [51].

Our findings represent a new model of antibody-dependent enhancement (ADE) of HIV-1 infection. Previous studies have demonstrated ADE in vitro due to Fc $\gamma \mathrm{R}$ - or complement-mediated mechanisms or to modulation of the interaction of gp120 with CGR5 [52,53,54]. Here we demonstrate that enhancement in vitro occurs at the level of transcytosis across epithelial cells and involves $\mathrm{FcRn}$. In vivo, Ig isotype, as well as neutralizing activity, are likely to play a determining role in whether an antibody might protect from or enhance infection. As demonstrated recently, intrarectally applied dIgAl HGN194 mAb, but less so the IgGl version, prevented SHIV infection following intrarectal challenge [40]. In vitro, the dIgAl inhibited transcytosis, whereas we now show that the IgGl version enhances transcytosis at $\mathrm{pH}$ 6.0. Another study showed that, compared to irrelevant- and no-antibody controls, there was an increase in the number of transmitted/founder SHIV variants when vaginal challenge followed systemic or local infusion of a non-neutralizing IgG1 mAb [55]. Clearly, other studies have found that $\operatorname{IgG}$ with neutralizing activity can prevent lentivirus infection after vaginal challenge [56,57]. Thus, whereas a strong vaccine-induced neutralizing $\operatorname{IgG}$ response may protect, nonneutralizing IgG or waning titers of neutralizing IgG present in an acidic lumen might enhance transcytosis across mucosal barriers while allowing infection of susceptible target cells. However, whether an antibody protects, enhances or has no effect is likely to depend on the potency and breadth of antiviral activity, the viral strain, the inflammatory state of the exposed individual, and genetic factors - such as Fc $\gamma \mathrm{R}$ polymorphisms - that might influence antibody function [58]. Finally, if FcRn-mediated transcytosis applies in vivo, our results would strengthen the argument for a mucosal IgA response to vaccination - though not at the exclusion of a strong IgG neutralizing or other anti-viral response - since IgA can inhibit transcytosis, would not engage $F_{C} R n$, and mediates only uni-directional translocation of immune complexes from the subepithelial space into external secretions $[40,59]$.

Some studies have reported that anti-HIV-1 Env IgG antibodies can inhibit transcytosis $[9,60,61]$. One of these studies found that polyclonal anti-HIV Env IgG inhibited transcytosis of cell-free virus on HEC-1 cells, whereas none of $13 \mathrm{mAbs}$ did; in fact, some of the mAbs might have increased transcytosis, although by no more than about $50 \%$ [61]. To our knowledge, none of these studies was carried out under the acidic conditions that characterize female genital tract secretions.

Our results suggest that FcRn might facilitate infection in hosts without pre-existing antibody or with a non-neutralizing IgG response to prior infection (which would result in secondary infection) or to vaccination. However, FcRn could also play a beneficial role in preventing infection after exposure. FcRn mediates the bidirectional transcytosis of $\mathrm{IgG}$, and in immunized individuals, could provide a conduit for antibodies to neutralize virus as shown for herpes simplex virus type 2 [19]. In addition, IgG immune complexes can prime CD4+ and CD8+ T cells in an FcRn-dependent manner, and FcRn targeting may be a useful mucosal immunization strategy [62,63,64].

In summary, we have demonstrated that FcRn mediates enhanced transcytosis of HIV-1 in the presence of low $\mathrm{pH}$ and $\mathrm{HIV}$-1-specific antibody. We have also shown that $\mathrm{F}_{\mathrm{C}} \mathrm{Rn}$ is present on epithelial cells in areas of the genital tract that are potentially exposed to HIV-1 during sexual intercourse. Our findings point toward a novel mechanism by which the sexual transmission of HIV-1 may be facilitated.

\section{Methods}

\section{Ethics statement}

This research was approved by the Institutional Review Boards at the University of California, Irvine, Boston University, and the University of Alabama, Birmingham. Subjects from whom specimens were collected for study purposes provided written informed consent.

\section{Cell lines, cell culture media, and viruses}

Human Endometrial Carcinoma (HEG-1A) cells (ATCG) were propagated in Modified McCoy's 5a Medium, and Human Colon Carcinoma (T84) cells (ATCG) in Dulbecco's modified Eagle's medium; media were supplemented with $2.5 \mathrm{mM} \mathrm{L}$-glutamine (Gibco, Invitrogen Technologies), 1\% Penstrep (Gellgro Mediatech Inc.) and $10 \%$ FBS (Atlas Biologicals) and maintained at $37^{\circ} \mathrm{C}$ with 5\% CO2. TZM-bl cells (NIH AIDS Reagent Program) for infectivity assays were propagated in RPMI 1640 supplemented with L-glutamine, Penstrep and 10\% FBS as above. Five primary clinical HIV-1 strains, HIV-1 ${ }_{\text {US657 }}, \mathrm{HIV}_{-1} \mathrm{US712}_{2}, \mathrm{HIV}-1_{\text {JRFL, }}$, HIV-1 ${ }_{\text {HT593, }}$, and HIV-1 ${ }_{\text {HT599 }}$ were obtained from the NIH AIDS Reagent Program. SHIV 1157 ipEL-p, provided by Ruth Ruprecht, was grown in rhesus peripheral blood mononuclear cells [65].

\section{Antibodies}

HIVIG (IgG derived from pooled plasma of HIV-infected individuals) and IgG1 monoclonal antibodies (mAbs) 2F5, 4E10, 2G12, F240, b6, and VRC01 were obtained from the NIH AIDS 
Reagents Program. IVIG (Gamunex, Taleris Biotherapeutics) was commercially acquired. mAb b12 and control mAb Den3 were provided by Dennis Burton and Brian Moldt, and control mAb Fm-6 was a gift of Wayne Marasco (Dana-Farber Cancer Institute); b12 and the control mAbs are IgGl. Generation and purification of dimeric and monomeric IgA2 versions of b12 (dIgA2 b12 and mIgA2 b12) are described elsewhere [66]. Briefly, the IgG constant region in pDR.12 (IgG b12) was replaced with the constant region of IgA2. IgA2 b12 was expressed in CHO-K1 cells with human $\mathrm{J}$ chain and purified by Protein $\mathrm{L}$ affinity matrix (Pierce). mIgA b12 and dIgA b12 were isolated by size exclusion chromatography. IgG1 HGN194 (a human mAb against HIV-1 Env V3), dIgA1 HGN194, and dIgA2HGN194 were provided by Davide Corti and Antonio Lanzavecchia [67]. HGN194 variants were constructed as follows: human $\mathrm{J}$ chain precursor (accession number NP_653247), IgAl (allele IGHAl*01, accession number J00220) and IgA2 (allele IGHA2*01, accession number J00221) constant region nucleotide sequences were codon optimized and synthesized by Genscript. Constant regions were cloned into a mammalian expression vector used for subcloning of the HGN194 VH region. The HGN194 VH and VL chain were codon optimized and synthesized by Genscript and cloned into an IgG1 and Ig-lambda expression vector. MAbs HGN194 dIgA1, dIgA2, and IgG1 were produced by transient transfection of 293 freestyle cells with polyethylenimine and expression plasmids encoding corresponding heavy and light chains (in the case of dIgAl and dIgA2, the J chain expression plasmid was included). Supernatant fluid from transfected cells was collected after 7-10 days of culture. HGN194 dIgA1, dIgA2, and IgG1 were affinity purified by Peptide M (dIgAl and dIgA2) or Protein A (IgG1) chromatography. Purified Abs were quantified by ELISA using dIgAl and dIgA2 or IgG1-specific Abs (Southern Biotech). Purity and polymeric state of $\mathrm{dIgAl}$ and $\mathrm{dIgA} 2$ were confirmed by nativePAGE analysis and gel filtration chromatography. The presence of dIgAl and dIgA2 associated J-chain was confirmed by Western blot from native and SDS-PAGE gels. Sera from 20 Zambian clade C-infected subjects (obtained from Zdenek Hel, University of Alabama, Birmingham) were pooled for IgG isolation using the Pierce Melon Gel IgG Spin Purification Kit (Thermo Scientific) according to the manufacturer's instructions. Env-specific IgG, determined as for CVL and seminal fluid (see below), was $0.98 \%$ of total IgG. Sera from five uninfected individuals were pooled and processed for IgG isolation in the same manner.

Fc mutants designed to enhance (M428L) or reduce (I253A) mAb b12 binding to FcRn were constructed as follows: briefly, the b12 variable regions were PCR-amplified from pDR 12 and cloned into the prlHC and pkLC vectors $[68,69]$. Amino acid substitutions were introduced by QuikChange site-directed mutagenesis (Stratagene, La Jolla, CA). Constructs were verified by sequence analysis before transiently expressed in FreeStyle 293 cells (Invitrogen, Carlsbad, CA) and purified by protein A affinity chromatography (GE Healthcare, United Kingdom).

\section{Virus neutralization assay}

Antibodies were tested for neutralizing activity against indicated HIV-1 strains using TZM-bl cells.

\section{Virus capture assay}

Half-area 96-well plates (Corning) were coated with $5 \mu \mathrm{g} / \mathrm{ml}$ (250 ng/well) of goat anti-human Fc antibody and incubated over night at $4{ }^{\circ} \mathrm{C}$. Plates were then washed with PBS and blocked with $4 \%$ non-fat dry milk for 1 hour at room temperature (RT). After washing, capture antibodies were added at $5 \mu \mathrm{g} / \mathrm{ml}(250 \mathrm{ng} /$ well), and plates were incubated an additional hour at RT. Next, virus was added to washed plates (20 ng p24/well) and incubated for 3 hours at $37^{\circ} \mathrm{C}$. Unbound virus was removed by washing with PBS. Subsequently, $1 \times 10^{4}$ TZM-bl cells/well were added in the presence of $10 \mu \mathrm{g} / \mathrm{ml}$ DEAE dextran and incubated for 48 hours at $37^{\circ} \mathrm{C}$. Cells were then washed, lysed, and developed with luciferase assay reagent according to the manufacturer's instructions (Promega). Luminescence (relative light units) was measured using a Synergy 2 microplate luminometer (BioTek).

\section{Antibody binding assays}

We measured binding of antibodies either to virus directly coated on ELISA-plate wells or to solubilized Env. For the direct virus binding assay, plates were coated with HIV-1 JR-FL $(20 \mathrm{ng}$ p24/well) for 2 hours at $37^{\circ} \mathrm{C}$, washed with PBS and blocked with $4 \%$ non-fat dry milk in PBS. After 1 hour at $37^{\circ} \mathrm{C}$, plates were washed, antibodies were added in serial dilutions and incubated for 1 hour at $37^{\circ} \mathrm{C}$. Detector antibody (horse radish peroxidaselabeled goat anti-human $\mathrm{Fc}$ ) was added to the washed plate and incubated for $45 \mathrm{~min}$ at $37^{\circ} \mathrm{C}$. Finally, plates were washed, developed (TMB solution, Life Technologies), and read at $450 \mathrm{~nm}$ using a plate reader (BioTek).

The soluble Env binding assay was performed as previously described with some modifications [70]. Briefly, wells were coated with $250 \mathrm{ng}$ of a gp120 Env specific anti-C5-antibody (D7324 [Aalto Bioscience]), washed and blocked with 4\% non-fat dry milk. Serial dilutions of detergent-solubilized HIV-1 JR-FL (starting at $150 \mathrm{ng}$ p24) was added and incubated for 2 hours at $37^{\circ} \mathrm{C}$. Plates were then incubated with a constant concentration of antibodies $(1 \mu \mathrm{g} / \mathrm{mL})$ for 1 hour at $37^{\circ} \mathrm{C}$ followed by detection and development steps as described above.

\section{Clade C transmitted/founder Env pseudotyped virus}

Five R5 clade $\mathrm{C}$ transmitted/founder Env pseudotyped strains were constructed as described [71,72]. Briefly, rev-vpu-env cassettes from the transmitted founder strains were cloned into pcDNA 3.1D/V5-HIS TOPO ${ }^{\circledR}$ expression vector. The pseudotyped viruses were then produced by co-transfecting $293 \mathrm{~T}$ cells with pcDNA 3.1(rev-vpu-env), pNL4-3.lucR-E-, and fugene 6 (Roche).

\section{Cervicovaginal and seminal fluid $\lg G$}

Cervicovaginal lavage (CVL) and seminal fluid were collected from HIV-1-infected patients and healthy volunteers at the University of Alabama, Birmingham. All subjects gave written consent in accordance with an IRB-approved protocol. CVL was collected from one 34 year-old uninfected women and from three infected women (age 29 to 46 years) with CD4+ lymphocyte counts of $458 / \mathrm{mm}^{3}, 181 / \mathrm{mm}^{3}$ and $498 / \mathrm{mm}^{3}$ and plasma viral loads of 14100 copies/ml, 824 copies $/ \mathrm{ml}$ and 88 copies $/ \mathrm{ml}$, respectively. Viral loads were not measured in the GVL fluid specimens. Two of the women (with the lower plasma viral loads) were receiving anti-retroviral therapy. Briefly, CVL fluid was obtained by flushing the cervix and vagina with $5 \mathrm{ml}$ sterile saline, and the wash was collected into tubes with protease inhibitors ([73]). Seminal fluid was obtained from two uninfected men (ages 25 and 40 years), and from three infected men (age 43 to 53 years) by masturbation (58). CD4 counts in the infected men were 404/ $\mathrm{mm}^{3}, 336 / \mathrm{mm}^{3}$ and $407 / \mathrm{mm}^{3}$ and plasma viral loads were $<100$ copies/ml, 8092 copies/ml and 6750 copies/ml, respectively; only one of these subjects (with viral load of 11 copies/ml) was receiving anti-retroviral therapy. Seminal fluid was assayed for HIV-1 RNA by PCR, but none was detected. The cervicovaginal and seminal fluids were centrifuged and supernatant fluids aliquoted and frozen at $-80^{\circ} \mathrm{C}$ until assayed. Total IgG was determined by ELISA 
[74]. IgG isolation was accomplished by incubating samples with Protein G-Sepharose (GE Healthcare Bio-Sciences Corp.) followed by elution of bound IgG according to manufacturer's instructions. The IgG preparations were concentrated and dialyzed against DPBS using Amicon Centrifugal Filter Units (Millipore Corp.). The IgG preparations from the two uninfected men were pooled to obtain sufficient quantity for experiments; all other IgG preparations were tested individually.

Env-specific IgG binding levels in seminal and CVL fluids were quantified by ELISA. Detergent-solubilized Env from HIV-1 ${ }_{\text {US657 }}$ was captured by a polyclonal sheep anti-gp120 antibody (D7324, Aalto Bio Reagents Ltd). Sample IgG and an anti-gp120 mAb standard (b6) were serially diluted, added to wells, washed, and detected by anti-human IgG (gamma)-HRP (Sigma-Aldrich, A6029) antibody. Plates were subsequently developed, stopped, and read at $\mathrm{OD}_{450} \mathrm{~nm}$. The concentrations of Env-specific IgG in the seminal and CVL IgG samples were calculated using the mAb b6 standard and are reported as a percent of total $\mathrm{IgG}$ in each sample.

Anti-Env IgG ranged from 0.9 to $2.6 \%$ of total $\mathrm{IgG}$ in the seminal fluid specimens and from 0.1 to $0.6 \%$ of total $\mathrm{IgG}$ in the CVL fluids specimens (Figure S6).

\section{Dual chamber transcytosis assay}

Transcytosis assays were conducted using reproductive tractderived (human endometrial carcinoma [HEC-1A]) or intestinal tract-derived (human colonic carcinoma [T84]) cells. HEC1-1A or T84 cell monolayers were created on $0.4 \mu \mathrm{m}$ polyethylene terephthalate membrane hanging transwell inserts (Millipore). Cell viability was $>95 \%$ at the time of plating. Electrical resistance across the membrane, which ranged from $400-450 \mathrm{mOhms} / \mathrm{cm}^{2}$ at the start of the transcytosis assay, confirmed monolayer integrity. Resistance was re-measured after the transcytosis assay in more than $50 \%$ of wells and ranged from $450-480 \mathrm{mOhms} /$ $\mathrm{cm}^{2}$. HIV-1 alone or with antibody was added to monolayers in media buffered to $\mathrm{pH} 6.0$ or 7.4. After 12 hours, fluid in the lower chamber ("subnatant fluid"), maintained at $\mathrm{pH} 7.4$, was collected and used to measure viral RNA copy number and infectivity. In the absence of cell monolayers, about $69 \%$ of the virus inoculum was present in the lower chamber of the wells after 12 hours.

\section{Viral RNA extraction and quantitative RT-PCR}

Viral RNA was extracted from cell-free subnatant fluid using PureLink Viral RNA Mini Kits (Invitrogen) or NucleoSpin RNA Virus extraction kits (Macherey Nagel Inc.), according to the manufacturers' instructions. Quantitative one-step real-time RTPCR of extracted HIV-1 viral RNA was done using Quantitect SYBR Green RT-PCR kits (Qiagen $\mathrm{GmbH}$ ) and that of SHIV $_{1157 i p E L-p}$ with Rotor Gene Probe RT-PCR kits according to the manufacturers' instructions. HIV-lgag primers: SK462 d(AGTTGGAGGA-CATCAAGCAGCGATGCAAAT) and SK431 d(TGCTATGTCAGTTCCGCTTGGTTGTCT) (AnaSpec Inc.). SIV-1 gag primers: d(GGG AGA TGG GGG TGA GAA A) and d(CGT TGG GTC GTA GCG TAA TTT T). SIV-1 gag probe: d(TCA TGT GGT TTG TTG CGT GAC AAG AGG GA) (Integrated DNA Technologies, Inc.).

\section{Infectivity assays}

$150 \mu \mathrm{l}$ of subnatant fluid was used to infect $1 \times 10^{4}$ TZM-bl cells. TZM-bl cells were lysed 2 days post-infection with $1 \mathrm{X}$ Cell Culture Lysis Reagent (Promega Corp.), and luciferase activity was determined by chemiluminescence using Luciferase Substrate (Promega Corp.).

\section{FcRn knockdown of HEC-1A cells}

HEC-1A cells were transduced with FcRn shRNA Lentiviral Particles (Santa Cruz Biotechnology Inc.) following manufacturer's protocol. Cells were selected in medium containing $5 \mu \mathrm{g} / \mathrm{ml}$ Puromycin dihydrochloride (Sigma-Aldrich Inc.), and FcRn expression was verified by flow cytometry using rabbit polyclonal anti-FcRn antibody (Santa Cruz Biotechnology Inc.), normal rabbit IgG (negative control) and FITC-goat anti-rabbit IgG $\mathrm{F}\left(\mathrm{ab}^{\prime}\right) 2$ secondary antibody (Jackson ImmunoResearch Laboratories Inc.) (Figure S3A). Cytofix/Cytoperm Plus Kits (BD Biosciences) were used to fix, permeabilize and stain cells. Knockdown of FcRn was also confirmed by western blot using rabbit anti-FcRn antibody (Novus Biologicals) (Figure S3A). Wild-type and knockdown cells had similar viability. Neither wildtype nor knockdown HEC-1A cells stained for Fc $\gamma$ RIIa or Fc $\gamma$ RIIIa (not shown).

FcRn blocking and inhibition of endosomal acidification

HEC-1A cells were incubated with $50 \mu \mathrm{g} / \mathrm{ml} \mathrm{rabbit} \mathrm{polyclonal}$ anti-FcRn IgG (H-274; Santa Cruz Biotechnology Inc.) or normal rabbit polyclonal IgG for 1 hour at $\mathrm{pH} 7.4$ before exposing the apical surface to HIV-1 $1_{\text {US712 }}$ and HIVIG, b12, IVIG or Synagis. Similarly, HEC-1A cells were incubated with $0.1 \mu \mathrm{M}$ bafilomycin Al (Santa Cruz Biotechnology Inc.) for 1 hour prior to HIV-1 and antibody exposure. Transcytosis was then carried out as above.

\section{Detection of FcRn protein expression in human genital tissues by immunohistochemistry}

Cervical tissue, which included portions of endocervix and upper vagina (ectocervix), was obtained from 10 women aged $31-$ 50 undergoing hysterectomy for nonmalignant conditions. Vaginal tissue was also obtained from women undergoing vaginal repair $(\mathrm{n}=6$, aged $44-78$ years). Penile tissue, including urethra $(\mathrm{n}=16)$ and foreskin $(\mathrm{n}=2)$, was harvested at autopsy from 16 men aged 34-73 with no history of hormonal or immunosuppressive medications. Tissues were processed within 60 minutes of surgical removal. Samples were either embedded in Tissue-Tek Optimal Cutting Temperature Compound (Sakura Finetek U.S.A., Inc.) and rapidly frozen and stored at $-70^{\circ} \mathrm{C}$ (frozen sections) or were fixed in formaldehyde and processed for paraffin embedding.

The alkaline phosphatase immunohistology technique was described previously ([75]). Two anti-FcRn antibodies were used: 1) Anti-FcRn antibody purified from rabbit serum raised against ๙2 (88-177aa) and $\alpha 3$ (1782-247aa) domains of human FcRn (provided by Neil Simister, Brandeis University) for use on frozen sections (Figure 5), and 2) rabbit anti-FcRn antibody obtained from Novus Biologicals for use on paraffin sections following citrate buffer ( $\mathrm{pH}$ 6.0) antigen retrieval (Figure S7). Sections were blocked with serum-free protein solution, and optimally diluted primary FcRn antibodies or rabbit IgG (negative control) were added and incubated for 1-2 hours at RT. Binding of antibodies to $\mathrm{FcRn}$ in tissues was visualized using an alkaline phosphatase detection system that stains positive cells bright red. Sections were counterstained with hematoxylin and cover-slipped using aqueous mounting medium.

\section{Statistics}

Differences in amounts of transcytosed or infectious virus between conditions were compared using Kruskal-Wallis or repeated-measures ANCOVA. For repeated-measures ANCOVA, the percentage of transcytosed or infectious virus was logittransformed and normality evaluated using the Shapiro-Wilk test. 
Correlations between continuous variables were evaluated by Spearman's rho. Two-tailed $p$-values are reported.

\section{Supporting Information}

Figure S1 Transcytosis of HIV-1 at pH 6.0 over time. HIV$1_{\text {JRFL }}$ with HIVIG, IVIG or no antibody was applied to the apical surface of HEC-1A cells at $\mathrm{pH}$ 6.0. At the indicated times, subnatant fluid ( $\mathrm{pH} 7.4$ ) was collected, and transcytosis was quantified by RT-PCR.

(PPTX)

Figure S2 Antibody and low $\mathrm{pH}$-mediate enhanced transcytosis of HIV-1 across T84 colonic carcinoma cells. HIV-1 ${ }_{\text {US657 }}$ and the indicated concentrations of HIV-specific IgG (HIVIG) or control IgG (IVIG) were applied to the apical surface of T84 colonic carcinoma cells at $\mathrm{pH} 6.0$ or 7.4. After 12 hours, virus in the subnatant fluid was quantified by RT-PCR and expressed as a percentage of the inoculum added to the apical surface. Data represent the mean+SE of two independent experiments. Similar results were obtained in an additional experiment using another R5 strain of HIV-1 (HIV-1 US712).

(PPTX)

Figure S3 Enhanced transcytosis is due to FcRn. (A) Knockdown of HEC-1A cells was accomplished using lentivirus particles expressing small hairpin RNA and verified by flow cytometry (left panel) and Western blot (right panel) using rabbit polyclonal antiFcRn antibodies; $\mathrm{WT}=$ wild-type HEC-1A cells and $\mathrm{KD}=\mathrm{FcRn}$ knockdown HEC-1A cells. GAPDH was used as a protein-loading control. (B) Binding of wild-type mAb b12 and Fc mutants of b12 (M428L and I253A) to HIV-1 JRFL gp120 by ELISA is equivalent. (c) Neutralization of HIV-1 JRFL by wild-type b1 2 and its Fc mutants are similar. $\mathrm{IC}_{50}$ values for wild-type b12, M428L, and I253A are 0.03 , 0.04 , and $0.02 \mu \mathrm{g} / \mathrm{ml}$, respectively. (D-F) Enhanced transcytosis of HIV-1 is blocked by bafilomycin Al and by an anti-FcRn antibody. HIVIG and $\mathrm{HIV}_{\text {US657 }}(\mathbf{D})$ or HIVIG or mAb b12 and $\mathrm{HIV}_{\text {US712 }}(\mathbf{E}$, F) were added to the apical surface of HEC-1A cells at $\mathrm{pH} 6.0$ in the presence or absence of $0.1 \mu \mathrm{M}$ bafilomycin Al $(\mathbf{D}-\mathbf{F})$ or in the presence of rabbit polyclonal anti-FcRn IgG $(50 \mu \mathrm{g} / \mathrm{ml})$ or normal rabbit polyclonal IgG ("Neg antibody") $(\mathbf{E}, \mathbf{F})$. Data represent mean $+\mathrm{SE}$ of two independent experiments $(\mathbf{D})$ or single experiments $(\mathbf{E}$, F). (G) Non-HIV-specific mAb (Den3) inhibits VRC01-mediated enhancement of transcytosis of HIV-1 at $\mathrm{pH}$ 6.0. Immune complexes, made with $25 \mu \mathrm{g} / \mathrm{ml}$ of VRC01 and HIV-1 ${ }_{\text {JRFL }}$, were added to the apical surface of HEC-1A cells in the presence of indicated concentrations of Den3 at $\mathrm{pH}$ 6.0. Subnatant fluid ( $\mathrm{pH}$ 7.4) was collected 12 hours later, and virus was quantified by

\section{References}

1. Cohen MS (2004) HIV and sexually transmitted diseases: lethal synergy. Top HIV Med 12: 104-107.

2. Galvin SR, Cohen MS (2004) The role of sexually transmitted diseases in HIV transmission. Nat Rev Microbiol 2: 33-42.

3. Fanibunda SE, Modi DN, Gokral JS, Bandivdekar AH (2011) HIV gp120 binds to mannose receptor on vaginal epithelial cells and induces production of matrix metalloproteinases. PLoS One 6: e28014.

4. Mesman AW, Geijtenbeek TB (2012) Pattern Recognition Receptors in HIV Transmission. Front Immunol 3: 59.

5. Ballweber L, Robinson B, Kreger A, Fialkow M, Lentz G, et al. (2011) Vaginal langerhans cells nonproductively transporting HIV-1 mediate infection of $\mathrm{T}$ cells. J Virol 85: 13443-13447.

6. Kage A, Shoolian E, Rokos K, Ozel M, Nuck R, et al. (1998) Epithelial uptake and transport of cell-free human immunodeficiency virus type 1 and gp120coated microparticles. J Virol 72: 4231-4236.

7. Saidi H, Magri G, Carbonneil C, Bouhlal H, Hocini H, et al. (2009) Apical interactions of HIV type 1 with polarized HEC-1 cell monolayer modulate R5HIV type 1 spread by submucosal macrophages. AIDS Res Hum Retroviruses 25: 497-509.
RT-PCR. Numbers above the bars indicate the \% inhibition of transcytosis. Data represent mean $+\mathrm{SE}$ of two independent experiments. (H) Maximum transcytosis in the presence of HIV-1specific antibody occurs at $\mathrm{pH}$ 5.5-6.0. HIV-1 JRFL was incubated with HIVIG $(50 \mu \mathrm{g} / \mathrm{ml})$ at indicated $\mathrm{pH}$ values and added to the apical surface of HEC-1A cells. Transcytosis was quantified by RTPCR in subnatant fluid collected 6- and 12-hours later. Note that IVIG and no antibody controls, used at pH 6.0 only, gave similarly low levels of transcytosis compared to HIVIG at pH 7.4 (not shown). (PPTX)

Figure S4 Transcytosis of $\mathrm{IgG}$ alone is influenced by $\mathrm{pH}$ at the apical cell surface. $50 \mu \mathrm{g} / \mathrm{ml}$ of mAbs Den3 or VRC01 were added to the apical side of HEC-1A cells. Twelve hours later, IgG was quantified in the subnatant fluid by ELISA.

(PPTX)

Figure S5 Transcytosis of HIV-1 ${ }_{\text {JRFL }}$ correlates directly with $\mathrm{mAb}$ binding and inversely with neutralizing activity. (A) $\mathrm{mAb}$ binding by ELISA to HIV-1 JRFL directly coated on plates. (B) Correlation between $\mathrm{mAb}$ binding and transcytosis at $50 \mu \mathrm{g} / \mathrm{ml}$ of mAb (Spearman $r h o=0.75 ; p=0.052$ ). $(\mathbf{C})$ Correlation between $\mathrm{IC}_{50}$ (see Figure 3E) and transcytosis at $50 \mu \mathrm{g} / \mathrm{ml}$ of $\mathrm{mAb}$ (Spearman $r h o=-0.71 ; p=0.050)$.

(PPTX)

Figure S6 Anti-monomeric Env binding activity of CVL and seminal fluid IgG as a percentage of total IgG. The dotted line represents a negative cutoff based on the mean+2 SD of IgG from cervicovaginal and seminal fluid of the HIV-uninfected subjects. Shown is the mean+SE of two independent assays, each done in duplicate.

(PPTX)

Figure S7 Additional examples of FcRn expression in the columnar epithelia of human penile urethra and endocervix. (A) Penile, $(\mathbf{B})$ endocervical or $(\mathbf{G})$ vaginal tissue was stained with affinity-purified anti-human-FcRn rabbit IgG or with normal rabbit $\operatorname{IgG}(\mathbf{D}, \mathbf{E})$. Staining was performed on frozen tissue sections.

(PPTX)

\section{Author Contributions}

Conceived and designed the experiments: SG JSG JM DJA DNF. Performed the experiments: SG JSG JCB TBP JP ZM SBJ GL MJS LHP DC. Analyzed the data: DJA DNF. Contributed reagents/materials/ analysis tools: ZM BM ZH AL RMR DRB JM. Wrote the paper: SG DJA DNF.

8. Bobardt MD, Chatterji U, Selvarajah S, Van der Schueren B, David G, et al. (2007) Cell-free human immunodeficiency virus type 1 transcytosis through primary genital epithelial cells. J Virol 81: 395-405.

9. Shen R, Drelichman ER, Bimczok D, Ochsenbauer C, Kappes JC, et al. (2010) GP41-specific antibody blocks cell-free HIV type 1 transcytosis through human rectal mucosa and model colonic epithelium. J Immunol 184: 3648-3655.

10. Cannon G, Yi Y, Ni H, Stoddard E, Scales DA, et al. (2008) HIV envelope binding by macrophage-expressed gp 340 promotes HIV-1 infection. J Immunol 181: 2065-2070.

11. Viard M, Parolini I, Rawat SS, Fecchi K, Sargiacomo M, et al. (2004) The role of glycosphingolipids in HIV signaling, entry and pathogenesis. Glycoconj J 20: $213-222$.

12. Alfsen A, Yu H, Magerus-Chatinet A, Schmitt A, Bomsel M (2005) HIV-1infected blood mononuclear cells form an integrin- and agrin-dependent viral synapse to induce efficient HIV-1 transcytosis across epithelial cell monolayer. Mol Biol Cell 16: 4267-4279.

13. Stoddard E, Cannon G, Ni H, Kariko K, Capodici J, et al. (2007) gp340 expressed on human genital epithelia binds HIV-1 envelope protein and facilitates viral transmission. J Immunol 179: 3126-3132. 
14. Stoddard E, Ni H, Cannon G, Zhou C, Kallenbach N, et al. (2009) gp340 promotes transcytosis of human immunodeficiency virus type 1 in genital tractderived cell lines and primary endocervical tissue. J Virol 83: 8596-8603.

15. Raux M, Finkielsztejn L, Salmon-Ceron D, Bouchez H, Excler JL, et al. (2000) IgG subclass distribution in serum and various mucosal fluids of HIV type 1infected subjects. AIDS Res Hum Retroviruses 16: 583-594.

16. Wright PF, Kozlowski PA, Rybczyk GK, Goepfert P, Staats HF, et al. (2002) Detection of mucosal antibodies in HIV type 1-infected individuals. AIDS Res Hum Retroviruses 18: 1291-1300.

17. Yates NL, Stacey AR, Nolen TL, Vandergrift NA, Moody MA, et al. (2013) HIV-1 gp41 envelope IgA is frequently elicited after transmission but has an initial short response half-life. Mucosal Immunol 6(4):692-703.

18. Mestecky J, Jackson S, Moldoveanu Z, Nesbit LR, Kulhavy R, et al. (2004) Paucity of antigen-specific IgA responses in sera and external secretions of HIVtype 1-infected individuals. AIDS Res Hum Retroviruses 20: 972-988.

19. Li Z, Palaniyandi S, Zeng R, Tuo W, Roopenian DC, et al. (2011) Transfer of $\mathrm{IgG}$ in the female genital tract by MHC class I-related neonatal Fc receptor (FCRn) confers protective immunity to vaginal infection. Proc Natl Acad Sci U S A 108: 4388-4393.

20. Kuo TT, Baker K, Yoshida M, Qiao SW, Aveson VG, et al. (2010) Neonatal Fc receptor: from immunity to therapeutics. J Clin Immunol 30: 777-789.

21. Roopenian DC, Sun VZ (2010) Clinical ramifications of the MHC family $F_{C}$ receptor FcRn. J Clin Immunol 30: 790-797.

22. Akilesh S, Christianson GJ, Roopenian DC, Shaw AS (2007) Neonatal FcR expression in bone marrow-derived cells functions to protect serum IgG from catabolism. J Immunol 179: 4580-4588.

23. Simister NE, Story CM, Chen HL, Hunt JS (1996) An IgG-transporting Fc receptor expressed in the syncytiotrophoblast of human placenta. Eur J Immunol 26: $1527-1531$.

24. Raghavan M, Gastinel LN, Bjorkman PJ (1993) The class I major histocompatibility complex related $\mathrm{Fc}_{\mathrm{c}}$ receptor shows $\mathrm{pH}$-dependent stability differences correlating with immunoglobulin binding and release. Biochemistry 32: 8654-8660.

25. Linhares IM, Summers PR, Larsen B, Giraldo PC, Witkin SS (2011) Contemporary perspectives on vaginal $\mathrm{pH}$ and lactobacilli. Am J Obstet Gynecol 204: 120 e121-125.

26. Caillouette JC, Sharp CF, Jr., Zimmerman GJ, Roy S (1997) Vaginal pH as a marker for bacterial pathogens and menopausal status. Am J Obstet Gynecol 176: 1270-1275; discussion 1275-1277.

27. Atashili J, Poole C, Ndumbe PM, Adimora AA, Smith JS (2008) Bacterial vaginosis and HIV acquisition: a meta-analysis of published studies. AIDS 22: 1493-1501.

28. Bouvet JP, Gresenguet G, Belec L (1997) Vaginal pH neutralization by semen as a cofactor of HIV transmission. Clin Microbiol Infect 3: 19-23.

29. Fox CA, Meldrum SJ, Watson BW (1973) Continuous measurement by radiotelemetry of vaginal $\mathrm{pH}$ during human coitus. J Reprod Fertil 33: 69-75.

30. Nugent SG, Kumar D, Rampton DS, Evans DF (2001) Intestinal luminal pH in inflammatory bowel disease: possible determinants and implications for therapy with aminosalicylates and other drugs. Gut 48: 571-577.

31. Lisco A, Munawwar A, Introini A, Vanpouille C, Saba E, et al. (2012) Semen of HIV-1-infected individuals: local shedding of herpesviruses and reprogrammed cytokine network. J Infect Dis 205: 97-105.

32. Sheth PM, Kovacs C, Kemal KS, Jones RB, Raboud JM, et al. (2009) Persistent HIV RNA shedding in semen despite effective antiretroviral therapy. AIDS 23: 2050-2054.

33. Hawes SE, Sow PS, Stern JE, Critchlow GW, Gottlieb GS, et al. (2008) Lower levels of HIV-2 than HIV-1 in the female genital tract: correlates and longitudinal assessment of viral shedding. AIDS 22: 2517-2525.

34. Yoshida M, Claypool SM, Wagner JS, Mizoguchi E, Mizoguchi A, et al. (2004) Human neonatal Fc receptor mediates transport of IgG into luminal secretions for delivery of antigens to mucosal dendritic cells. Immunity 20: 769-783.

35. Maidji E, McDonagh S, Genbacev O, Tabata T, Pereira L (2006) Maternal antibodies enhance or prevent cytomegalovirus infection in the placenta by neonatal Fc receptor-mediated transcytosis. Am J Pathol 168: 1210-1226.

36. Martin WL, West AP, Jr., Gan L, Bjorkman PJ (2001) Crystal structure at 2.8 A of an $\mathrm{FcRn} /$ heterodimeric $\mathrm{Fc}$ complex: mechanism of $\mathrm{pH}$-dependent binding. Mol Cell 7: 867-877.

37. Hinton PR, Johlfs MG, Xiong JM, Hanestad K, Ong KC, et al. (2004) Engineered human IgG antibodies with longer serum half-lives in primates. J Biol Chem 279: 6213-6216.

38. Mathur A, Arora T, Liu L, Grouse-Zeineddini J, Mukku V (2013) Qualification of a homogeneous cell-based neonatal $\mathrm{Fc}_{\mathrm{c}}$ receptor ( $\mathrm{FcRn}$ ) binding assay and its application to studies on Fc functionality of IgG-based therapeutics. J Immunol Methods 390: 81-91

39. Lee CH, Choi DK, Choi HJ, Song MY, Kim YS (2010) Expression of soluble and functional human neonatal Fc receptor in Pichia pastoris. Protein Expr Purif 71: $42-48$.

40. Watkins JD, et al. (2013) Anti-HIV IgA isotypes: differential virion capture and inhibition of transcytosis are linked to prevention of mucosal R5 SHIV transmission. AIDS 27(9):F13-20.

41. Ramalingam TS, Detmer SA, Martin WL, Bjorkman PJ (2002) IgG transcytosis and recycling by $\mathrm{FCRn}$ expressed in MDCK cells reveals ligand-induced redistribution. EMBO J 21: 590-601.
42. Story CM, Mikulska JE, Simister NE (1994) A major histocompatibility complex class I-like $\mathrm{F}_{\mathrm{c}}$ receptor cloned from human placenta: possible role in transfer of immunoglobulin G from mother to fetus. J Exp Med 180: 2377-2381.

43. Lu L, Palaniyandi S, Zeng R, Bai Y, Liu X, et al. (2011) A neonatal Fc receptortargeted mucosal vaccine strategy effectively induces HIV-1 antigen-specific immunity to genital infection. J Virol 85: 10542-10553.

44. Myer L, Wright TC, Jr., Denny L, Kuhn L (2006) Nested case-control study of cervical mucosal lesions, ectopy, and incident HIV infection among women in Cape Town, South Africa. Sex Transm Dis 33: 683-687.

45. Moss GB, Clemetson D, D'Costa L, Plummer FA, Ndinya-Achola JO, et al. (1991) Association of cervical ectopy with heterosexual transmission of human immunodeficiency virus: results of a study of couples in Nairobi, Kenya. J Infect Dis 164: $588-591$.

46. Jacobson DL, Peralta L, Graham NM, Zenilman J (2000) Histologic development of cervical ectopy: relationship to reproductive hormones. Sex Transm Dis 27: 252-258.

47. Pudney J, Oneta M, Mayer K, Seage G, (1992) Pre-ejaculatory fluid as potential vector for sexual transmission of HIV-1. Lancet 340: 1470.

48. Owen DH, Katz DF (1999) A vaginal fluid simulant. Contraception 59: 91-95.

49. Gray RH, Kigozi G, Serwadda D, Makumbi F, Watya S, et al. (2007) Male circumcision for HIV prevention in men in Rakai, Uganda: a randomised trial. Lancet 369: 657-666.

50. Cohen CR, Lingappa JR, Baeten JM, Ngayo MO, Spiegel CA, et al. (2012) Bacterial vaginosis associated with increased risk of female-to-male HIV-1 transmission: a prospective cohort analysis among African couples. PLoS Med 9: e1001251.

51. Wilen CB, Parrish NF, Pfaff JM, Decker JM, Henning EA, et al. (2011) Phenotypic and immunologic comparison of clade B transmitted/founder and chronic HIV-1 envelope glycoproteins. J Virol 85: 8514-8527.

52. Takeda A, Sweet RW, Ennis FA (1990) Two receptors are required for antibody-dependent enhancement of human immunodeficiency virus type 1 infection: CD4 and Fc gamma R. J Virol 64: 5605-5610.

53. Robinson WE, Jr., Montefiori DC, Mitchell WM (1988) Antibody-dependent enhancement of human immunodeficiency virus type 1 infection. Lancet 1: 790794.

54. Guillon G, Schutten M, Boers PH, Gruters RA, Osterhaus AD (2002) Antibodymediated enhancement of human immunodeficiency virus type 1 infectivity is determined by the structure of gp120 and depends on modulation of the gp120CCR5 interaction. J Virol 76: 2827-2834.

55. Burton DR, Hessell AJ, Keele BF, Klasse PJ, Ketas TA, et al. (2011) Limited or no protection by weakly or nonneutralizing antibodies against vaginal SHIV challenge of macaques compared with a strongly neutralizing antibody. Proc Natl Acad Sci U S A 108: 11181-11186.

56. Veazey RS, Shattock RJ, Pope M, Kirijan JC, Jones J, et al. (2003) Prevention of virus transmission to macaque monkeys by a vaginally applied monoclonal antibody to HIV-1 gp120. Nat Med 9: 343-346.

57. Hessell AJ, Hangartner L, Hunter M, Havenith CE, Beurskens FJ, et al. (2007) $\mathrm{Fc}$ receptor but not complement binding is important in antibody protection against HIV. Nature 449: 101-104.

58. Forthal DN, Gabriel EE, Wang A, Landucci G, Phan TB (2012) Association of Fcgamma receptor IIIa genotype with the rate of HIV infection after gp120 vaccination. Blood 120: 2836-2842.

59. Wright A, Lamm ME, Huang YT (2008) Excretion of human immunodeficiency virus type 1 through polarized epithelium by immunoglobulin A. J Virol 82: $11526-11535$.

60. Tudor D, Yu H, Maupetit J, Drillet AS, Bouceba T, et al. (2012) Isotype modulates epitope specificity, affinity, and antiviral activities of anti-HIV-1 human broadly neutralizing 2F5 antibody. Proc Natl Acad Sci U S A 109: $12680-12685$.

61. Chomont N, Hocini H, Gody JC, Bouhlal H, Becquart P, et al. (2008) Neutralizing monoclonal antibodies to human immunodeficiency virus type 1 do not inhibit viral transcytosis through mucosal epithelial cells. Virology 370: 246254.

62. Qiao SW, Kobayashi K, Johansen FE, Sollid LM, Andersen JT, et al. (2008) Dependence of antibody-mediated presentation of antigen on FcRn. Proc Natl Acad Sci U S A 105: 9337-9342.

63. Baker K, Qiao SW, Kuo TT, Aveson VG, Platzer B, et al. (2011) Neonatal Fc receptor for IgG $(\mathrm{FcRn})$ regulates cross-presentation of IgG immune complexes by CD8-CD11b+ dendritic cells. Proc Natl Acad Sci U S A 108: 9927-9932.

64. Liu X, Lu L, Yang Z, Palaniyandi S, Zeng R, et al. (2011) The neonatal FcRmediated presentation of immune-complexed antigen is associated with endosomal and phagosomal $\mathrm{pH}$ and antigen stability in macrophages and dendritic cells. J Immunol 186: 4674-4686.

65. Siddappa NB, Watkins JD, Wassermann KJ, Song R, Wang W, et al. (2010) R5 clade C SHIV strains with tier 1 or 2 neutralization sensitivity: tools to dissect env evolution and to develop AIDS vaccines in primate models. PLoS One 5: e11689.

66. Mantis NJ, Palaia J, Hessell AJ, Mehta S, Zhu Z, et al. (2007) Inhibition of HIV1 infectivity and epithelial cell transfer by human monoclonal IgG and IgA antibodies carrying the b12 V region. J Immunol 179: 3144-3152.

67. Corti D, LangedijkJP, Hinz A, Seaman MS, Vanzetta F, et al. (2010) Analysis of memory $\mathrm{B}$ cell responses and isolation of novel monoclonal antibodies with neutralizing breadth from HIV-1-infected individuals. PLoS One 5: e8805. 
68. Tiller T, Meffre E, Yurasov S, Tsuiji M, Nussenzweig MC, et al. (2008) Efficient generation of monoclonal antibodies from single human $\mathrm{B}$ cells by single cell RT-PCR and expression vector cloning. J Immunol Methods 329: 112-124.

69. Burton DR, Pyati J, Koduri R, Sharp SJ, Thornton GB, et al. (1994) Efficient neutralization of primary isolates of HIV-1 by a recombinant human monoclonal antibody. Science 266: 1024-1027.

70. Gach JS, Quendler H, Tong T, Narayan KM, Du SX, et al. (2013) A Human Antibody to the CD4 Binding Site of gp120 Capable of Highly Potent but Sporadic Cross Clade Neutralization of Primary HIV-1. PLoS One 8: e72054.

71. Keele BF, Giorgi EE, Salazar-Gonzalez JF, Decker JM, Pham KT, et al. (2008) Identification and characterization of transmitted and early founder virus envelopes in primary HIV-1 infection. Proc Natl Acad Sci U S A 105: 75527557.
72. Kraus MH, Parrish NF, Shaw KS, Decker JM, Keele BF, et al. (2010) A rev1vpu polymorphism unique to HIV-1 subtype A and C strains impairs envelope glycoprotein expression from rev-vpu-env cassettes and reduces virion infectivity in pseudotyping assays. Virology 397: 346-357.

73. Jackson S MJ, Moldoveanu Z, Spearman P. (2005) Appendix I: Collection and processing of human mucosal secretions. ; Mestecky J, Bienenstock J, Lamm ME, Mayer L, McGhee JR, Strober W., editor. Amsterdam: Elsevier/Academic Press.

74. Moldoveanu Z, Mestecky J (2009) Mucosal antibody responses to HIV. Methods Mol Biol 485: 333-345.

75. Pudney J, Quayle AJ, Anderson DJ (2005) Immunological microenvironments in the human vagina and cervix: mediators of cellular immunity are concentrated in the cervical transformation zone. Biol Reprod 73: 1253-1263. 